\title{
Habitat Climate Change Vulnerability Index Applied to Major Vegetation Types of the Western Interior United States
}

\author{
Patrick J. Comer ${ }^{1, *}$, Jon C. Hak ${ }^{1}$, Marion S. Reid ${ }^{1}$, Stephanie L. Auer ${ }^{2}$, Keith A. Schulz ${ }^{1}$, \\ Healy H. Hamilton ${ }^{2}$, Regan L. Smyth ${ }^{2}$ and Matthew M. Kling ${ }^{3}$ \\ 1 NatureServe, 1680 38th Street, Suite 120, Boulder, CO 80301, USA \\ 2 NatureServe, 2511 Richmond Highway, Suite 930, Arlington, VA 22202, USA \\ 3 Department of Integrative Biology, University of California, Berkeley, CA 94720, USA \\ * Correspondence: pcomer0318@gmail.com; Tel.: +1-703-797-4802
}

Received: 20 May 2019; Accepted: 3 July 2019; Published: 6 July 2019

\begin{abstract}
We applied a framework to assess climate change vulnerability of 52 major vegetation types in the Western United States to provide a spatially explicit input to adaptive management decisions. The framework addressed climate exposure and ecosystem resilience; the latter derived from analyses of ecosystem sensitivity and adaptive capacity. Measures of climate change exposure used observed climate change (1981-2014) and then climate projections for the mid-21st century (2040-2069 RCP 4.5). Measures of resilience included (under ecosystem sensitivity) landscape intactness, invasive species, fire regime alteration, and forest insect and disease risk, and (under adaptive capacity), measures for topo-climate variability, diversity within functional species groups, and vulnerability of any keystone species. Outputs are generated per $100 \mathrm{~km}^{2}$ hexagonal area for each type. As of 2014, moderate climate change vulnerability was indicated for $>50 \%$ of the area of 50 of 52 types. By the mid-21st century, all but 19 types face high or very high vulnerability with $>50 \%$ of the area scoring in these categories. Measures for resilience explain most components of vulnerability as of 2014, with most targeted vegetation scoring low in adaptive capacity measures and variably for specific sensitivity measures. Elevated climate exposure explains increases in vulnerability between the current and mid-century time periods.
\end{abstract}

Keywords: adaptive capacity; climate change vulnerability; exposure; resilience; sensitivity; vegetation

\section{Introduction}

Climate change represents a globally pervasive stress on natural ecosystems. Temperature and precipitation regimes drive ecosystem productivity and natural dynamics, such as the rate of plant growth, the frequency of natural wildfire, and seasonal streamflow [1]. Paleoecological research has shown that past episodes of climate change triggered transformation of natural communities at regional and local scales with varying speed and magnitude [2,3]. As the rate of climate change increases, substantial shifts in key ecological processes are likely to cascade through natural communities, resulting in altered productivity, change in species composition, local extinctions, and many instances of ecological degradation or collapse [4].

Conservation practitioners often lack a sufficient understanding of the many linkages between changing climate and key ecological processes. Nor do they fully understand the many interactions of climate-induced stress with other ecological stressors, such as those tied to land use, which may have already reduced the resiliency of many natural communities [5]. However, because of the controlling 
link between climate and many ecological processes, and the individualistic responses of component species, natural communities could transform in unprecedented ways [6,7]. Therefore, in any given place, a transparent assessment of climate change vulnerability for natural communities is needed to help quantify risk of ecological degradation or collapse.

A repeatable and transparent index of climate change vulnerability designed for natural communities helps to determine those types that, in all or part of their distribution, are most at risk of climate change impacts. It can provide an early warning of elevated risk for associated species, and a baseline for developing scientifically grounded, ecosystem-based strategies for climate change adaptation. This Habitat Climate Change Vulnerability Index (HCCVI) presented in this paper integrates variables from other assessments and results in products that support practical decision making and communication.

\section{Vulnerability Assessment at Different Levels of Ecological Organization}

Climate change vulnerability assessments may address different levels of ecological organization, such as species, communities, or landscapes. The species level is the most common focus for vulnerability assessment and consequently has received extensive attention in the literature [8-11]. Based in autecology, trait-based approaches examine projected climate change where the species occurs, aspects of the genetic variation, natural history, physiology, and landscape context to assess sensitivity and adaptive capacity [12].

Assessments of landscapes often produce spatially explicit results for interpretation at regional scales. Evaluation of exposure may result in maps showing where climate stress is indicated to be greatest, whereas examination of the potential climate-change effects on disturbance regimes or invasive species can address aspects of sensitivity [13-15]. Adaptive capacity can be measured through examination of the heterogeneity of topography, moisture gradients, or microclimates under the assumption that more diverse landscapes provide more opportunities for organisms to find climate refugia than homogeneous ones [16].

Assessing the vulnerability of natural community types can provide a useful complement to both landscape and species assessments. Whereas landscape assessments indicate a high potential for climate-change impacts in certain regions, analysis of component communities is based on synecology and aims to more directly measure how climate change will impact species assemblages, ecological processes, structure and function, and is a next logical step to identify practical adaptation strategies where local management of vegetation is a common form of resource management [7].

Few examples exist for assessing vulnerability at the community level of organization. In two examples, they assessed vulnerability of European forests [17], and coastal communities [18], but both took conceptual approaches based on these socio-ecological systems at continental scales. They were concerned mainly about ecosystem outputs of goods and services and aiming to inform societal responses in forestry and fisheries sectors.

In one recent example focusing more squarely at natural community types themselves [19], 31 major vegetation types in California were assessed considering climate projections by the year 2100, sensitivity and adaptive capacity estimates of dominant species for each type, and spatial disruption that might inhibit species movement over time. They used a basin characterization model [20] to express climate change exposure. Working at a global scale, assessment for terrestrial ecosystems [21] emphasized the need to address all three factors of exposure, sensitivity, and adaptive capacity.

Here, we demonstrate a practical framework for climate change vulnerability assessment, focusing on natural community types themselves. This current assessment builds upon prior efforts [22] to address major vegetation types, such as sagebrush shrubland and pinyon-juniper woodlands [23], with an initial focus on types that dominate lands managed by the Bureau of Land Management (BLM) in the conterminous Western US. Several of these types also have extensive distributions in neighboring Mexico or Canada. Below we explain our methods with the outputs of each step illustrated with one 
common sagebrush shrubland type, and then summarize findings and discuss implications for all 52 types that extend over 3.2 million $\mathrm{km}^{2}$ of Western North America.

We integrate measures of climate exposure with a series of measures for ecosystem resilience. Our intent is to complete analysis of terrestrial ecosystems or natural community types conceptualized at relatively local scales. Our approach facilitates the accumulation of results for many ecosystem types occurring across countries and continents. Results from this form of ecologically based analysis can then be applied to climate change adaptation in a variety of socio-ecological contexts across the range of distribution of the natural community type.

\section{Materials and Methods}

\subsection{Analytical Framework for Vulnerability Assessment}

This index approach to vulnerability assessment aims to organize a series of sub-analyses in a coherent structure that will shed light on distinct components of vulnerability, so that each can be evaluated individually, or in combination. Our approach parallels related indexing of climate change vulnerabilities for species [24]. The components of climate change vulnerability are organized into primary categories of Exposure and Resilience. Resilience is further subdivided into subcategories of Sensitivity and Adaptive Capacity (Figure 1). For the HCCVI, these terms are defined as follows:

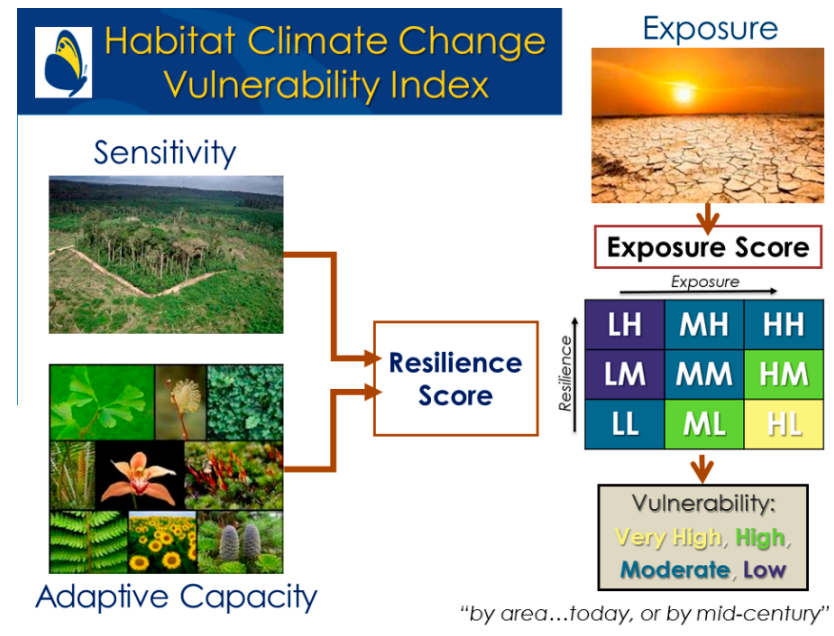

Figure 1. Analytical framework for the habitat climate change vulnerability index.

Exposure refers to the rate, magnitude, and nature of climate-induced stress on the community. Exposure encompasses trends in climate, such as changes in temperature and precipitation regimes, and any predicted effects on ecosystem-specific processes. Analyses of exposure consider change in climate variables themselves, or if possible, their resulting effects that cause increasing ecosystem stress, changing dynamic processes such as wildfire or hydrological regimes, or coastal dynamics. This definition of exposure aligns closely with other common applications to climate change vulnerability assessments where changing climate is viewed as an extrinsic driver or pressure on the system of interest [12].

Resilience encompasses intrinsic factors that are likely to affect ecological responses of the natural community to changing climate. These include factors commonly described for ecological resilience, as defined by Holling [25] and Gunderson [26]. Walker et al. [27] defined ecological resilience as "the capacity of a system to absorb disturbance and reorganize while undergoing change and while still retaining essentially the same function, structure, identity, and feedbacks." Under the broader measure of resilience, we include subcategories of Sensitivity and Adaptive Capacity.

- Sensitivity focuses on ecosystem stressors that are likely to affect ecological responses of the natural community to climate change. These emphasize human alterations to characteristic patterns and 
process that can be readily measured across the range of the community type, such as landscape fragmentation, effects of invasive species, or human alterations to other dynamic processes. These alterations are considered independent of climate change, but once identified, are likely to interact with changing climate.

- Adaptive Capacity includes natural characteristics that affect the potential for a natural community to cope with climate change. Analyses might consider the natural geophysical variability in climate for the type's distribution. They might also consider functional roles that characteristic species play, such as the relative vulnerabilities to climate change of individual species that provide "keystone" functions, and relative taxonomic diversity within key functional groups (e.g., C3- vs. C4-dominated communities) that characterize the type.

These definitions differ in part from those provided by the IPCC because here we emphasize synecology. Whereas sensitivity in species vulnerability is based more strongly on life history characteristics, natural communities encompass multiple species, each with differing tolerances. Here our sensitivity definition aims to better account for human alterations that affect the community composition and response to changing climate. Our adaptive capacity definition emphasizes natural characteristics of the community type-both biotic (species composition) and abiotic (geophysical), that may (or may not) contribute to resilience in the face of changing climate.

Drawing inspiration from Magness et al. [28] among others in structuring analyses with a logic model, the index scores combine information in two stages, with the first analyses gauging relative climate change resilience by combining scores from intrinsic factors of sensitivity and adaptive capacity. Climate change exposure and resilience are then considered together (combining extrinsic and intrinsic factors) to arrive at an overall gauge of climate change vulnerability (Figure 1).

The HCCVI uses component indicator values to ultimately arrive at a four-level series of scores, i.e., Very High, High, Moderate, and Low vulnerability (Figure 1). These can be derived from relative measures of both Resilience and Exposure. When using quantitative data for measurement, numerical scores are normalized to a 0.0 to 1 scale, with 0.0 indicating ecologically "least favorable" conditions, and 1 indicating "most favorable" conditions. Quartiles of each continuous measure may be used as a starting point to determine the range falling into each of the Very High-Low categories (e.g., $\geq 0.75=$ Low, $0.5-0.75=$ Moderate, $0.25-0.50=$ High, and $\leq 0.25=$ Very High overall vulnerability). In this application of the framework, all indicators are weighted equally, and we used an arithmetic mean for their combination. Different circumstances and datasets for component measures, or different needs for reporting, may suggest alternative weightings or thresholds to delineate these categories. See Tonmoy et al. [29] for a review of issues associated with indicator treatment in vulnerability assessments. For this framework, we emphasize the need to standardize indicator data in some form to enable combination with other component analysis results.

Very High climate change vulnerability results from combining high exposure with low resilience (i.e., both trending toward "least favorable" scores). These are circumstances where climate change stress and its effects are expected to be most severe, and relative resilience is lowest. Ecosystem transformation is most likely to occur in these types.

High climate change vulnerability results from combining either high or moderate exposure with low or medium resilience. Under either combination, climate change stress is anticipated to have considerable impact.

Moderate climate change vulnerability results from a variety of combinations for exposure and resilience; initially with circumstances where both are scored as moderate. However, this also results where resilience is scored high, if combined with either high or medium exposure. Where both resilience and exposure are low, some degree of climate change vulnerability remains.

Low climate change vulnerability results from combining low exposure with high resilience (i.e., both trending toward "most favorable" scores). These are circumstances where climate change stress and its effects are expected to be least severe or absent, and relative resilience is highest. 


\subsection{Spatial and Temporal Dimensions for Documenting Vulnerability}

Climate change vulnerability assessments need to be placed within explicit spatial bounds. For this effort, we summarized component measurements by $100 \mathrm{~km}^{2}$ hexagon for the distribution of each vegetation type, and then further summarized results within Level III of the Commission for Economic Cooperation (CEC) ecoregions [30] for each vegetation type (Figure 2). These ecoregions provide an appropriate and consistent spatial structure to systematically document climate change vulnerability at national or regional scales.

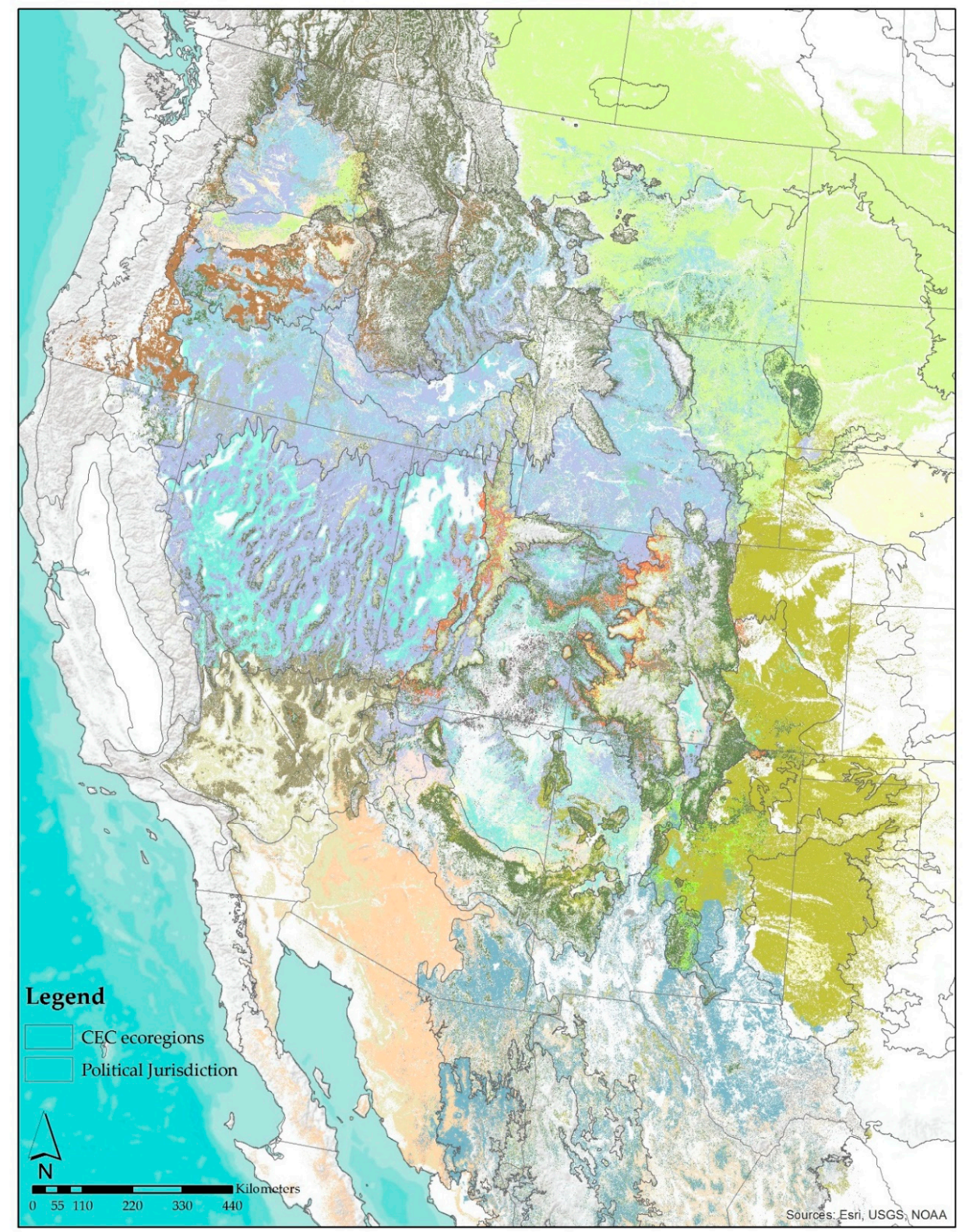

Figure 2. Mapped distributions of 52 ecological system types (too numerous to list here) in Western North America, centered on the USA, with boundaries of the Commission for Economic Cooperation CEC ecoregions [30] used for reporting on vulnerability.

Similarly, climate change vulnerability assessments require a temporal dimension because the magnitude of component measures could vary over time. For this effort, we based initial vulnerability measures on emerging or "current" climate trends using observed climate data (as of 2014). Given both uncertainties associated with climate projections, and the need to apply vulnerability assessments 
to decisions affecting resources in upcoming decades, climate projections over the upcoming 50-year timeframe (e.g., between 2020 and 2070) provide subsequent realistic timeframes where climate trends can be estimated within acceptable bounds of uncertainty. Therefore, we also assess vulnerability with the mid-21st century timeframe (2040-2069).

\subsection{Ecological Classification and Distribution}

For this project, we used NatureServe's terrestrial ecological systems classification to define types [31]. The advantage of using this classification system is that it represents an established classification of several hundred upland and wetland types that have been extensively described and mapped by US federal and state resource managers [32,33] and extended into adjacent Canada, Mexico, and across Latin America and the Caribbean [34]. The expected pre-Columbian, or "potential", distribution of each type, mapped at $90 \mathrm{~m}$ pixel resolution, was used as the base distribution for assessment (Figure 2). Descriptions of each type can be found at http://explorer.natureserve.org/. We completed additional literature review to further document each type with current knowledge of key ecological processes and stressors, and potential measures for assessing climate change resilience. We completed literature searches using individual communities/systems, common stressors, and functional species groups (e.g., "cool season") as key words using Google Scholar and Colorado State University Library Prospector.

Below, we discuss measures for climate change exposure and resilience applied to each type for this project. Appendix A includes a more detailed explanation of component measures used for ecosystem resilience. For purposes of illustrating our methodology, we will use one example-Intermountain Basins Big Sagebrush Shrubland to depict component steps of the HCCVI framework (Figures 3-7).

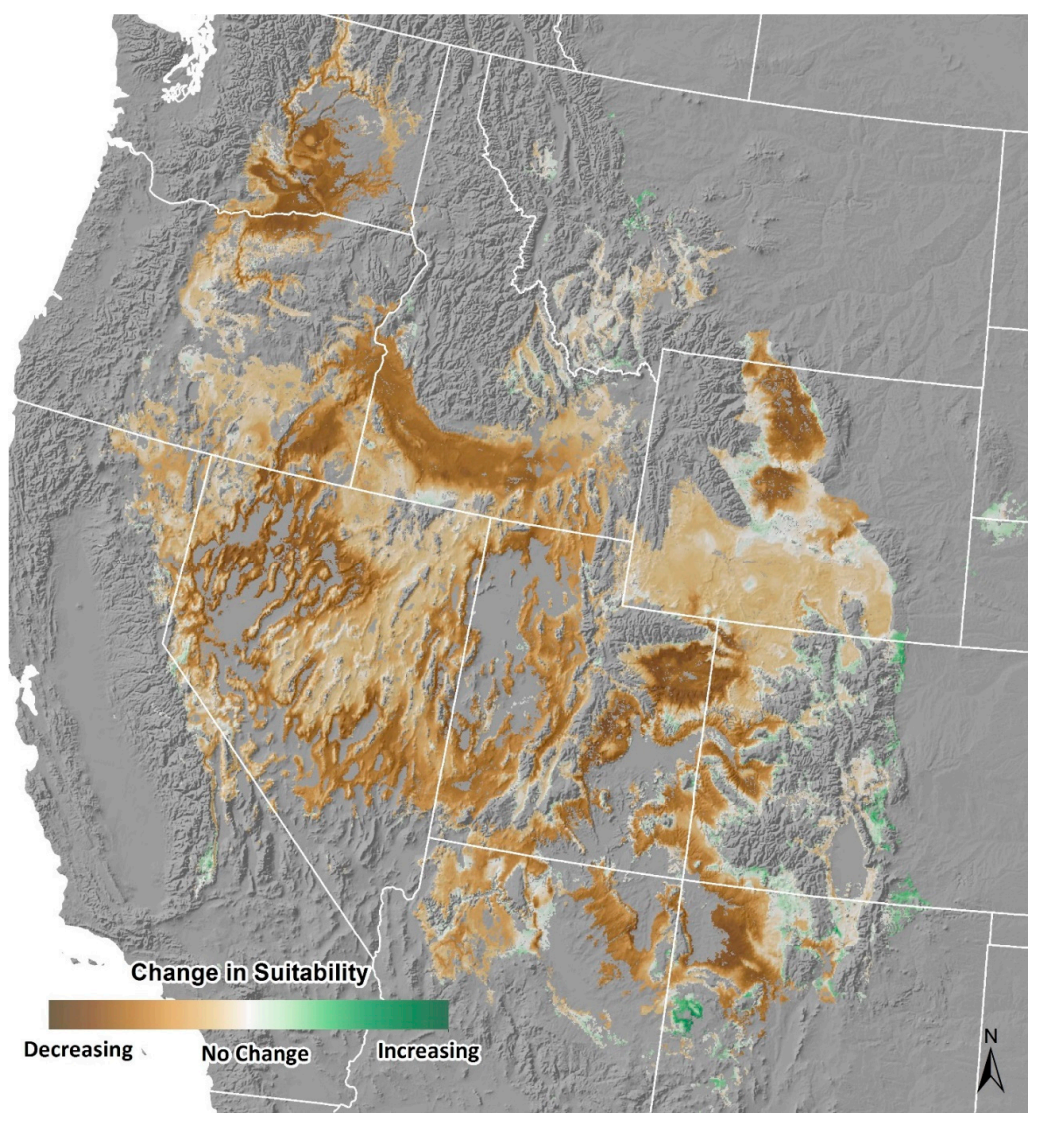

Figure 3. Change in Climate Suitability estimate for 2040-2070 timeframe for Intermountain Basins Big Sagebrush Shrubland. 


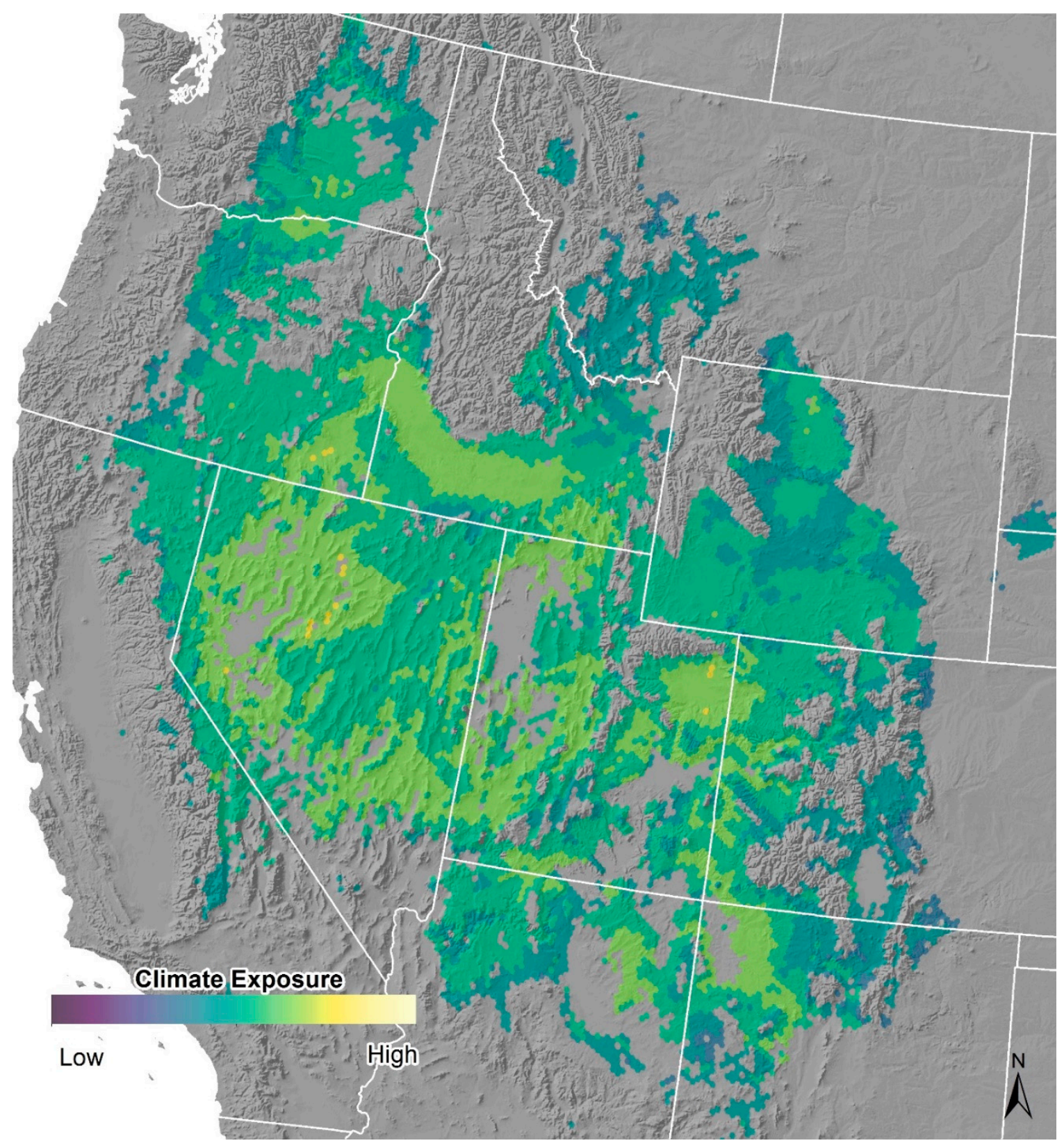

Figure 4. Climate Exposure estimate for 2040-2070 timeframe as index scores (i.e., low-high climate stress) summarized by $100 \mathrm{~km}^{2}$ hexagon for Intermountain Basins Big Sagebrush Shrubland. 


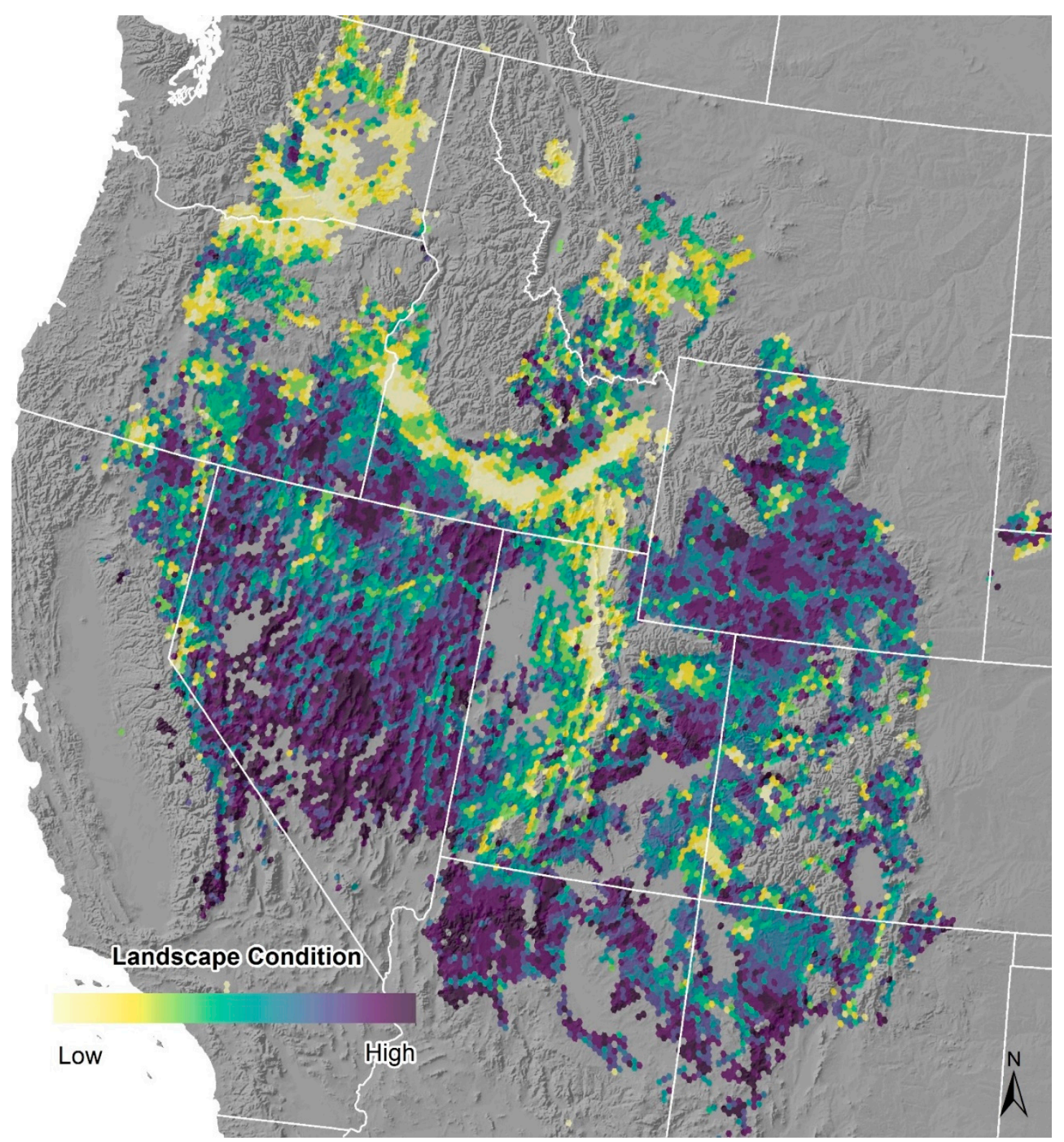

Figure 5. Sensitivity measure of landscape condition and index scores summarized by $100 \mathrm{~km}^{2}$ hexagon for Intermountain Basins Big Sagebrush Shrubland. 


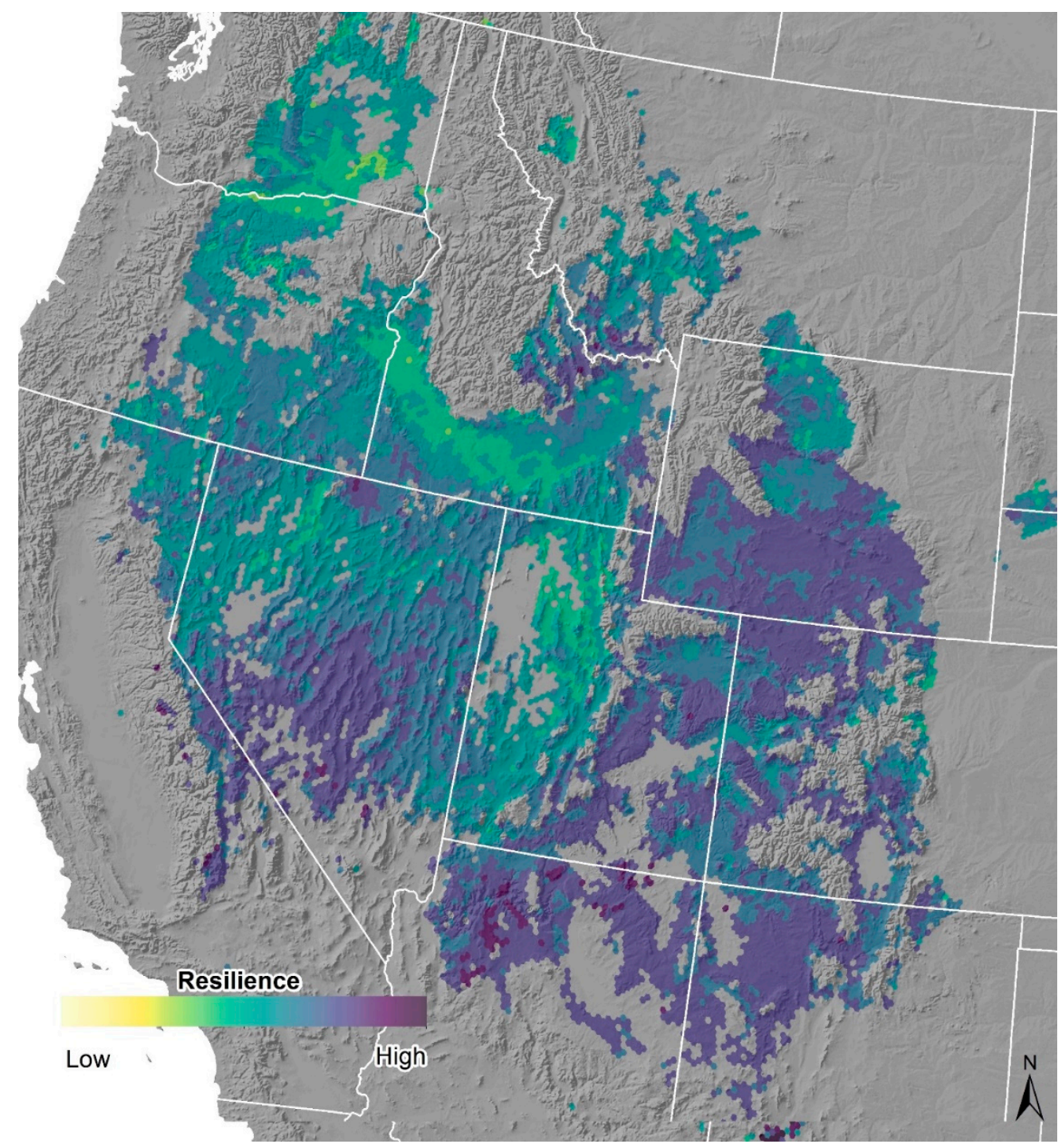

Figure 6. Overall Resilience measure summarized by $100 \mathrm{~km}^{2}$ hexagon for Intermountain Basins Big Sagebrush Shrubland. 


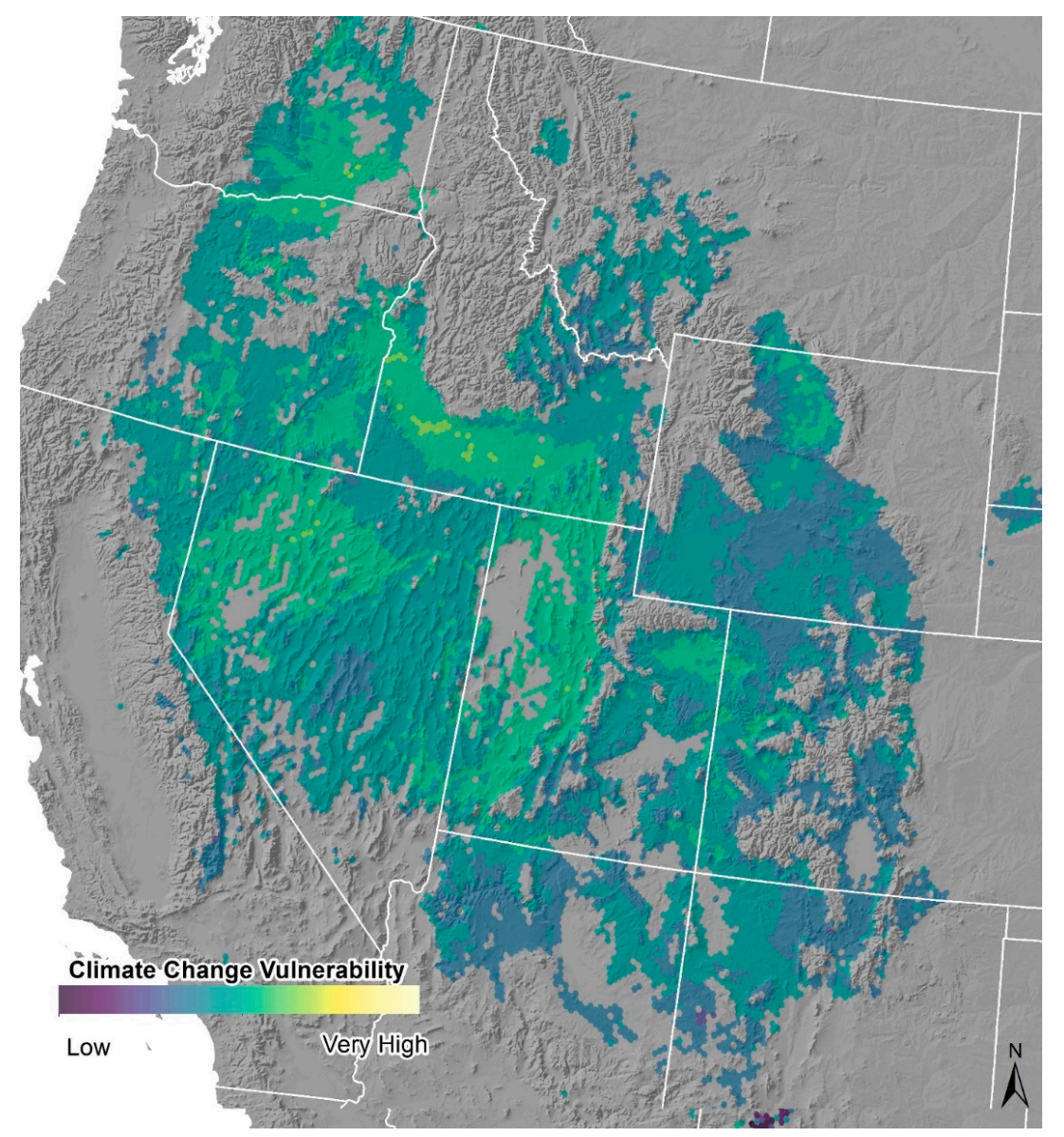

Figure 7. Overall Climate Change Vulnerability estimate for 2040-2070 summarized by $100 \mathrm{~km}^{2}$ hexagon for Intermountain Basins Big Sagebrush Shrubland.

\subsection{Climate Change Exposure}

We characterized the baseline climate niche for each vegetation type using historical climate data for the mid-20th century and the potential historical distribution of the type (detail below). This provides a baseline of suitable conditions from which to compare climate trends from subsequent time periods to clarify the significance of measurable change. The entire potential distribution for each community type was used to ensure that the entire range of possible suitable climate conditions was represented for each type. Using distributions that have been affected by land conversion could skew how we define climate suitability for a vegetation type and hence, how we measure climate exposure. Kling et al. [35] provide additional detail on component model design and performance.

For every grid cell of each vegetation type we calculated a composite index of climate change exposure as the sum of two distinct exposure measures: suitability change, which quantifies departure from the historical range of spatial climate variability across the geographic range of that vegetation type, and typicality, which quantifies departure from the historical range of year-to-year climate variability at a given pixel location. Each component index ranges from 0.0 to 0.5 ; these are summed to derive the final combined exposure index ranging from 0 (low climate exposure) to 1 (large climate exposure).

Exposure measures were calculated based on changes in 19 bioclimatic variables derived from monthly temperature and precipitation variables [36]. Using a historical baseline period representing typical 20th century climate (1948-1980), we estimated exposure for both recent observed climate change (1981-2014) and projected future change (2040-2069, RCP 4.5). While related regional analyses investigated differences between RCP 4.5 and 8.5 [37], and our methodology could accommodate either here we utilized just RCP 4.5. These calculations were initiated in 2015, and so at that time 2014 was the most recent climate data available. To maximize data quality across the full spatiotemporal extent 
of our analysis, we combined gridded climate datasets from several sources. Within the contiguous US, for the baseline and recent periods, temperature data were sourced from TopoWx [38] whereas precipitation data were sourced from PRISM version LT71 [39], both at $810 \mathrm{~m}$ resolution. Outside the US, and for the future within the US, all variables were based on $1 \mathrm{~km}^{2}$ data from ClimateNA [40].

The suitability change metric uses niche modeling to estimate changes in a site's climatic suitability for a given vegetation type for a given timeframe. For each vegetation type we fit a random forest [41] model using baseline means of the six most important (of 19) bioclimatic variables and 1,000 presence and absence locations sampled from within the rectangular bounding box of the type's geographic extent. The top six differ among types, but six variables consistently explained a high proportion of model variability. Our choice of RF over alternative Generalized Linear Models (GLM), Generalized Additive Models (GAM), and MaxEnt algorithms, as well as our selection of variables for each type, was based on extensive model performance testing using spatial block cross-validation [42] to control the overfitting that comes from spatial non-independence. Variables were selected using recursive feature elimination [43], with six judged as the best empirical tradeoff between performance and parsimony. The fitted models were used to predict suitability for baseline, current, and future periods. Suitability change was then calculated by subtracting suitability measures across these time periods, and then rescaling these differences into a $0-0.5$ index with 0 representing increasing or unchanged suitability, and 0.5 representing a large decrease in suitability.

The typicality metric compares a site's current or future mean climate to the mean and yearly variation during a baseline period. For a given climate variable, typicality is calculated as the proportion of baseline years whose absolute deviation from the baseline mean (e.g., in degrees C) is larger than the absolute deviation of the recent mean from the baseline mean. A value of 0 indicates no change, while a value of 1 indicates that the recent or future mean climate is more extreme, in either direction, than any individual year in the baseline period. For each vegetation type we calculated typicality for each of the same six climate variables used in the RF models, and then averaged them to derive a final typicality index. Final typicality values were divided by two to rescale them to the 0.0 to 0.5 range.

Typicality ( 0.0 to 0.5$)$ and Change in Climate Suitability (0.0 to 0.5$)$ measures were then added together to produce an overall exposure measure, resulting in per pixel values within a 0.0-1.0 range, with 1.0 indicating high climate exposure and 0.0 indicating no measurable climate exposure. These per-pixel values were subsequently inverted and averaged for one measure per $100 \mathrm{~km}^{2}$ hexagon. Figure 3 illustrates one example of mid-21st century estimates of increasing or decreasing climate suitability for one major big sagebrush vegetation type. One can see where most substantial decreases in climate suitability for this type are concentrated in such places as Southeastern Washington, the Snake River Plain of Southern Idaho, Northwestern Nevada, the Big Horn Basin of Wyoming, and the Uinta Basin of Utah.

Figure 4 depicts, for the same type, the result of combining typicality and change in suitability estimates, and then summarizing those per-pixel values to $100 \mathrm{~km}^{2}$ hexagons. Darker blue areas are forecasted to be least stressed (closer to 1 ) and yellow areas most stressed (closer to 0.0 ). This image indicates where a substantial proportion of the range-wide extent scores into the high-very high range of climate exposure.

\subsection{Resilience-Ecosystem Sensitivity and Adaptive Capacity}

Our measures of Resilience address predisposing conditions-such as extant ecosystem stressors, or natural abiotic or biotic characteristics of the type-that are likely to affect ecological responses of the natural community to changing climate. For example, if exposure measures indicate the need for component species to migrate toward other elevations or latitudes, but the natural landscape is fragmented by intensive land uses, the relative vulnerability of community types in that fragmented landscape could increase [44]. Similarly, the introduction of non-native species may displace native species and/or alter key dynamic processes such as wildfire regimes [45], and both could be exacerbated by climate change. These factors would describe relative climate change sensitivity for a natural 
community type. This differs in approach from species vulnerability assessments, in that they tend to focus on life-history traits of individual taxa.

Inherent adaptive capacity of natural communities could consider the natural geophysical variability in climate for the type's distribution or the functional roles of species in the community type. Again, climate exposure might indicate a high level of climate stress, natural communities occurring within topographically flat landscapes with potential to retain little variability in microclimates could lack any built-in buffer effects for component species. Likewise, if certain ecosystem functions, such as nitrogen fixation, are limited to one or a few species that characterize the natural community, this could bring additional vulnerability due to the potential for their extirpation over time.

Upon completion of a literature review of each type, and evaluation of available spatial data, we selected four primary indicators suitable for measuring relative sensitivity. To address effects of landscape fragmentation, we used a spatial model for landscape intactness or condition. Since many assessed types are known to be affected by invasive annual grass invasion, a model aiming to measure relative invasion severity was selected. Similarly, since most assessed types have a characteristic natural wildfire regime, a spatial model estimating fire regime departure was used. For forest types, measures of elevated risk from insects or diseases were identified. Three measures of adaptive capacity include both biotic and abiotic factors. Biotics factors included scoring of each type for diversity within identified key functional species groups and relative vulnerability of any identified "keystone" species. One measure of topo-climatic variability was applied for the distribution of each type.

In each of these cases involving spatial models, the model was overlain with the distribution of each vegetation type and scores were transformed to indicate a relative degree of sensitivity or adaptive capacity within a $0.0-1$ range, again with 0.0 indicating most severely impacted, or least favorable, conditions while 1 indicating highest integrity, or apparently unaltered, conditions. These scores were each summarized to average values per $100 \mathrm{~km}^{2}$ hexagon. Figure 5 depicts results from one sensitivity measure of landscape condition for Intermountain Big Sagebrush Shrubland. Darker blue areas indicate apparently least fragmented areas and yellow areas most fragmented. One can see where in substantial portions of this distribution, such as in Eastern Washington, across the Snake River Plain, and south along the Wasatch Front of Utah, this sagebrush type occurs in landscape highly fragmented by intensive land uses.

Again, Appendix A includes a detailed explanation of component measures used for ecosystem resilience.

\subsection{Overall Resilience Scores}

Overall resilience scores were derived by averaging results for each measure of Sensitivity and for Adaptive Capacity (Figure 1). This combination of up to four Sensitivity measures and up to three Adaptive Capacity measures were averaged together per $100 \mathrm{~km}^{2}$ hexagon to establish an overall score for resilience. As an example, Figure 6 depicts this overall measure for Intermountain Basins Big Sagebrush Shrubland. One can again see the general pattern of moderate to low resilience in the regional landscapes—-such as the Snake River Plain of Southern Idaho-where most intensive land use and effects of invasive plant species are concentrated.

\subsection{Overall Climate Change Vulnerability}

As noted in Figure 1, the combination of climate change exposure with resilience scores results in the relative vulnerability estimate for a given timeframe. Figure 7 depicts this result as projected for the mid-21st century for Intermountain Basins Big Sagebrush Shrubland. Patterns of vulnerability in this type vary across its distribution, as depicted with $100 \mathrm{~km}^{2}$ hexagons, and are driven strongly by climate change exposure measures, but are also substantially influenced by component measures of resilience (e.g., Figure 4). While per hexagon outputs are summarized along the $0.0-1$ continuum, summary statistics for climate change vulnerability may be desirable with categories expressed as "Very High" "High" Moderate" or "Low" (Figure 1). Here, we used default break-points with quartiles 
of each continuous measure to determine the range falling into each of the Very High-Low categories $(\geq 0.75=$ Low, $0.5-0.75=$ Moderate, $0.25-0.50=$ High , and $\leq 0.25=$ Very High overall vulnerability $)$. In the case of the Intermountain Basins Big Sagebrush Shrubland, nearly all its distribution is forecasted to fall within the "Moderate" vulnerability as of 2014 and in the "High" range of vulnerability by the mid-21st century.

\section{Results}

Results for the 52 vegetation types were arranged into 10 categories that reflect major ecological gradients of the region, from high-elevation "Cool Temperate Subalpine Woodlands" down to "Warm Desert Shrublands" (Table 1). This is a high-level summary of analysis scores and overall results for each vegetation type, with proportions of their respective distributions falling in each category (Low-Very High) of vulnerability. On the left are results pertaining to the current timeframe, using climate exposure measure from observed climate trends for the 1981-2014 timeframe. On the right are results using climate exposure measures for the 2040-2069 timeframe.

As of 2014, 50 of 52 types scored within the Moderate vulnerability score for $>50 \%$ of the rangewide extent. Seven types scored as High vulnerability with $>10 \%$ of the range-wide extent in this category. No type had $>1 \%$ of their range scoring in extreme of Very High vulnerability. Of those scoring currently as High Vulnerability, Sonora-Mojave Creosotebush Desert Scrub scored the highest, with 74\% of its area scoring as highly vulnerable. Other types currently scoring High are found in warm deserts (Apacherian-Chihuahuan Semi-Desert Grassland and Steppe, Sonoran Paloverde-Mixed Cacti Desert Scrub, Chihuahuan Mixed Desert and Thornscrub, and Western Great Plains temperate shrubland and steppe landscapes (Northwestern Great Plains Mixedgrass Prairie, Rocky Mountain Foothill Limber Pine-Juniper Woodland, Western Great Plains Sand Prairie, Northwestern Great Plains Shrubland) (Table 1).

The primary result of considering projected climate exposure for the mid-21st century was an apparent overall shift in vulnerability scores from Low-Moderate to High ranges (Table 1) for nearly all 52 vegetation types. By the mid-21st century, all but 19 types face high climate change vulnerability with $>50 \%$ of the area scoring in these categories. This change in overall vulnerability is of course driven by more severe climate exposure measures (into High and Very High categories). Fourteen types scored with over $90 \%$ of their distribution in the high vulnerability category (Table 1 ).

Appendix B provides a more detailed breakdown of the results, summarizing proportional range-wide area by type scoring for climate exposure (both current and mid-21st century timeframes) and for overall resilience and its component scores for sensitivity and adaptive capacity; each with proportions of range-wide extent falling into each of the four binned categories for relative vulnerability. Again, one can see the relative contribution of elevated climate change exposure in the mid-21st century timeframe, with 17 types having over $90 \%$ of their range within either the high or very high vulnerability ranges for mid-21st century exposure. These extremes are concentrated in subalpine and montane forests and woodlands, extending down to elevations supporting Ponderosa Pine Woodlands and Savannas. A second concentration of types is in the cool semi-desert shrublands such as xeric sagebrush and Mojave mid-elevation shrubland. Here we also see additional explanation of overall vulnerability scores coming from component measures for resilience. Overall resilience scores were proportionally often in moderate vulnerability, but with 10 types having $>50 \%$ extent in high vulnerability from their resilience scores. These types are concentrated at lower elevation woodland, shrubland, and grassland types. Overall resilience scores appear to be most strongly driven by specific measures under both sensitivity and adaptive capacity. While most proportional area of each type scored in low to moderate ranges for the combined sensitivity measures, most scored in the high range for adaptive capacity. 
Table 1. Terrestrial ecological system types assessed for climate change vulnerability, with percentage of mapped area that was scored from Low to Very High Vulnerability using either current climate exposure or those from climate projections to the mid-21st century. Types are organized by elevation-based category and subsequently sorted based on approximate historical extent.

\begin{tabular}{|c|c|c|c|c|c|c|c|c|c|}
\hline \multirow{3}{*}{ Climate Change Vulnerability } & \multirow{4}{*}{$\begin{array}{c}\text { Potential or } \\
\text { Historic Extent } \\
\quad\left(\mathrm{Km}^{2}\right)\end{array}$} & \multicolumn{4}{|c|}{ Current Vulnerability } & \multicolumn{4}{|c|}{ Mid-21st Century Vulnerability } \\
\hline & & Low & Mod & High & Very High & Low & Mod & High & Very High \\
\hline & & $\geq 0.75$ & $\begin{array}{l}\geq 0.5 \text { and } \\
<0.75\end{array}$ & $\begin{array}{l}\geq 0.25 \text { and } \\
\quad<0.5\end{array}$ & $<0.25$ & $\geq 0.75$ & $\begin{array}{l}\geq 0.5 \text { and } \\
<0.75\end{array}$ & $\begin{array}{l}\geq 0.25 \text { and } \\
<0.5\end{array}$ & $<0.25$ \\
\hline Terrestrial Ecological System Types & & (\% Area) & (\% Area) & (\% Area) & (\% Area) & (\% Area) & (\% Area) & (\% Area) & (\% Area) \\
\hline \multicolumn{10}{|l|}{ Cool Temperate Subalpine Woodlands } \\
\hline $\begin{array}{l}\text { Northern Rocky Mountain Subalpine Woodland and } \\
\text { Parkland }\end{array}$ & 64,645 & $5 \%$ & $94 \%$ & & & & $59 \%$ & $41 \%$ & \\
\hline Rocky Mountain Lodgepole Pine Forest & 16,068 & $17 \%$ & $83 \%$ & $0.05 \%$ & & & $21 \%$ & $79 \%$ & $0.2 \%$ \\
\hline \multicolumn{10}{|l|}{ Aspen \& Mountain Mahogany Forests and Woodlands } \\
\hline $\begin{array}{l}\text { Inter-Mountain Basins Aspen-Mixed Conifer Forest and } \\
\text { Woodland }\end{array}$ & 27,929 & $23 \%$ & $77 \%$ & & & & $24 \%$ & $76 \%$ & \\
\hline Rocky Mountain Aspen Forest and Woodland & 24,103 & $20 \%$ & $80 \%$ & $0.02 \%$ & & $0.01 \%$ & $81 \%$ & $19 \%$ & \\
\hline $\begin{array}{l}\text { Inter-Mountain Basins Curl-Leaf Mountain-Mahogany } \\
\text { Woodland and Shrubland }\end{array}$ & 7241 & $53 \%$ & $47 \%$ & & & & $32 \%$ & $68 \%$ & \\
\hline \multicolumn{10}{|l|}{ Montane Conifer Forests and Woodlands } \\
\hline $\begin{array}{l}\text { Northern Rocky Mountain Dry-Mesic Montane Mixed } \\
\text { Conifer Forest }\end{array}$ & 129,039 & $5 \%$ & $95 \%$ & $0.04 \%$ & & & $94 \%$ & $6 \%$ & \\
\hline $\begin{array}{l}\text { Middle Rocky Mountain Montane Douglas-Fir Forest } \\
\text { and Woodland }\end{array}$ & 25,585 & $14 \%$ & $86 \%$ & & & & $37 \%$ & $63 \%$ & \\
\hline $\begin{array}{l}\text { Southern Rocky Mountain Dry-Mesic Montane Mixed } \\
\text { Conifer Forest and Woodland }\end{array}$ & 15,430 & $1 \%$ & $99 \%$ & & & & $3 \%$ & $97 \%$ & \\
\hline $\begin{array}{l}\text { Southern Rocky Mountain Mesic Montane Mixed Conifer } \\
\text { Forest and Woodland }\end{array}$ & 8961 & $3 \%$ & $97 \%$ & & & & $5 \%$ & $95 \%$ & \\
\hline \multicolumn{10}{|l|}{ Ponderosa Pine Woodlands and Savannas } \\
\hline $\begin{array}{l}\text { Northern Rocky Mountain Ponderosa Pine Woodland } \\
\text { and Savanna }\end{array}$ & 49,197 & $11 \%$ & $79 \%$ & & & $0.002 \%$ & $63 \%$ & $22 \%$ & $0.1 \%$ \\
\hline Southern Rocky Mountain Ponderosa Pine Woodland & 38,713 & & $98 \%$ & $2 \%$ & & & $62 \%$ & $38 \%$ & \\
\hline $\begin{array}{l}\text { Northwestern Great Plains-Black Hills Ponderosa Pine } \\
\text { Woodland and Savanna }\end{array}$ & 18,193 & & $93 \%$ & $7 \%$ & & $0.3 \%$ & $100 \%$ & $0 \%$ & \\
\hline $\begin{array}{l}\text { California Montane Jeffrey Pine-(Ponderosa Pine) } \\
\text { Woodland }\end{array}$ & 13,264 & $2 \%$ & $98 \%$ & $0.01 \%$ & & & $1 \%$ & $99 \%$ & $0.3 \%$ \\
\hline Southern Rocky Mountain Ponderosa Pine Savanna & 12,892 & $1 \%$ & $99 \%$ & & & & $10 \%$ & $90 \%$ & \\
\hline East Cascades Oak-Ponderosa Pine Forest and Woodland & 470 & & $100 \%$ & & & & $3 \%$ & $97 \%$ & \\
\hline
\end{tabular}


Table 1. Cont

\begin{tabular}{|c|c|c|c|c|c|c|c|c|c|}
\hline \multirow{3}{*}{ Climate Change Vulnerability } & \multirow{4}{*}{$\begin{array}{c}\text { Potential or } \\
\text { Historic Extent } \\
\left(\mathrm{Km}^{2}\right)\end{array}$} & \multicolumn{4}{|c|}{ Current Vulnerability } & \multicolumn{4}{|c|}{ Mid-21st Century Vulnerability } \\
\hline & & Low & Mod & High & Very High & Low & Mod & High & Very High \\
\hline & & $\geq 0.75$ & $\begin{array}{l}\geq 0.5 \text { and } \\
<0.75\end{array}$ & $\begin{array}{l}\geq 0.25 \text { and } \\
<0.5\end{array}$ & $<0.25$ & $\geq 0.75$ & $\begin{array}{l}\geq 0.5 \text { and } \\
<0.75\end{array}$ & $\begin{array}{l}\geq 0.25 \text { and } \\
<0.5\end{array}$ & $<0.25$ \\
\hline Terrestrial Ecological System Types & & (\% Area) & (\% Area) & (\% Area) & (\% Area) & (\% Area) & (\% Area) & (\% Area) & (\% Area) \\
\hline \multicolumn{10}{|l|}{ Pinyon and Juniper Woodlands } \\
\hline Madrean Pinyon-Juniper Woodland & 44,866 & $0.04 \%$ & $97 \%$ & $3 \%$ & & $0.03 \%$ & $85 \%$ & $7 \%$ & \\
\hline Colorado Plateau Pinyon-Juniper Woodland & 39,898 & $0.1 \%$ & $100 \%$ & & & & $58 \%$ & $42 \%$ & \\
\hline Great Basin Pinyon-Juniper Woodland & 22,304 & $0.1 \%$ & $100 \%$ & $0.2 \%$ & & & $70 \%$ & $30 \%$ & \\
\hline Southern Rocky Mountain Pinyon-Juniper Woodland & 10,466 & $0.2 \%$ & $100 \%$ & & & & $45 \%$ & $55 \%$ & \\
\hline $\begin{array}{l}\text { Southern Rocky Mountain Juniper Woodland and } \\
\text { Savanna }\end{array}$ & 10,382 & & $100 \%$ & & & & $38 \%$ & $62 \%$ & \\
\hline $\begin{array}{l}\text { Columbia Plateau Western Juniper Woodland and } \\
\text { Savanna }\end{array}$ & 7784 & $3 \%$ & $95 \%$ & $3 \%$ & & & $28 \%$ & $72 \%$ & \\
\hline Inter-Mountain Basins Juniper Savanna & 1531 & & $99 \%$ & $1 \%$ & & & $1 \%$ & $99 \%$ & \\
\hline Rocky Mountain Foothill Limber Pine-Juniper Woodland & 1330 & $5 \%$ & $85 \%$ & $10 \%$ & & & $16 \%$ & $84 \%$ & \\
\hline Colorado Plateau Pinyon-Juniper Shrubland & 206 & & $95 \%$ & $5 \%$ & & & $38 \%$ & $62 \%$ & \\
\hline \multicolumn{10}{|l|}{ Cool Temperate Grasslands } \\
\hline Northwestern Great Plains Mixed Grass Prairie & 620,860 & & $68 \%$ & $32 \%$ & & $3 \%$ & $74 \%$ & $24 \%$ & \\
\hline Western Great Plains Sand Prairie & 107,307 & $0.003 \%$ & $90 \%$ & $10 \%$ & & & $2 \%$ & $98 \%$ & \\
\hline Columbia Plateau Steppe and Grassland & 23,913 & $0.09 \%$ & $100 \%$ & $0.04 \%$ & & & $48 \%$ & $52 \%$ & \\
\hline Inter-Mountain Basins Semi-Desert Grassland & 22,532 & $0.03 \%$ & $100 \%$ & $0.07 \%$ & & & $11 \%$ & $89 \%$ & \\
\hline $\begin{array}{l}\text { Northern Rocky Mountain Lower } \\
\text { Montane-Foothill-Valley Grassland }\end{array}$ & 19,327 & $1 \%$ & $97 \%$ & $1 \%$ & & & $67 \%$ & $33 \%$ & \\
\hline Southern Rocky Mountain Montane-Subalpine Grassland & 3054 & $0.4 \%$ & $99 \%$ & $0.2 \%$ & & & $3 \%$ & $97 \%$ & \\
\hline
\end{tabular}


Table 1. Cont.

\begin{tabular}{|c|c|c|c|c|c|c|c|c|c|}
\hline \multirow{3}{*}{ Climate Change Vulnerability } & \multirow{4}{*}{$\begin{array}{c}\text { Potential or } \\
\text { Historic Extent } \\
\left(\mathrm{Km}^{2}\right)\end{array}$} & \multicolumn{4}{|c|}{ Current Vulnerability } & \multicolumn{4}{|c|}{ Mid-21st Century Vulnerability } \\
\hline & & Low & Mod & High & Very High & Low & Mod & High & Very High \\
\hline & & $\geq 0.75$ & $\begin{array}{l}\geq 0.5 \text { and } \\
<0.75\end{array}$ & $\begin{array}{l}\geq 0.25 \text { and } \\
<0.5\end{array}$ & $<0.25$ & $\geq 0.75$ & $\begin{array}{l}\geq 0.5 \text { and } \\
<0.75\end{array}$ & $\begin{array}{l}\geq 0.25 \text { and } \\
<0.5\end{array}$ & $<0.25$ \\
\hline Terrestrial Ecological System Types & & (\% Area) & (\% Area) & (\% Area) & (\% Area) & (\% Area) & (\% Area) & (\% Area) & (\% Area) \\
\hline \multicolumn{10}{|l|}{ Cool Semi-desert \& Temperate Shrubland and Steppe } \\
\hline Inter-Mountain Basins Big Sagebrush Shrubland & 282,439 & $2 \%$ & $97 \%$ & $0.3 \%$ & & $0.01 \%$ & $73 \%$ & $27 \%$ & \\
\hline Inter-Mountain Basins Big Sagebrush Steppe & 182,114 & $2 \%$ & $97 \%$ & $0.1 \%$ & & & $35 \%$ & $65 \%$ & \\
\hline Inter-Mountain Basins Montane Sagebrush Steppe & 83,707 & $8 \%$ & $92 \%$ & $0.010 \%$ & & & $70 \%$ & $30 \%$ & \\
\hline Great Basin Xeric Mixed Sagebrush Shrubland & 62,126 & $7 \%$ & $93 \%$ & $0.003 \%$ & & & $8 \%$ & $92 \%$ & \\
\hline Mojave Mid-Elevation Mixed Desert Scrub & 54,768 & $1 \%$ & $99 \%$ & $0.3 \%$ & & & $19 \%$ & $81 \%$ & \\
\hline Columbia Plateau Low Sagebrush Steppe & 21,361 & $2 \%$ & $97 \%$ & $0.1 \%$ & & & $48 \%$ & $52 \%$ & \\
\hline Rocky Mountain Gambel Oak-Mixed Montane Shrubland & 19,637 & $0.0 \%$ & $100 \%$ & $0.01 \%$ & & & $3 \%$ & $96 \%$ & $0.47 \%$ \\
\hline Northwestern Great Plains Shrubland & 9786 & & $70 \%$ & $30 \%$ & & & $36 \%$ & $63 \%$ & $0.48 \%$ \\
\hline Colorado Plateau Blackbrush-Mormon-Tea Shrubland & 8366 & & $100 \%$ & & & & $13 \%$ & $87 \%$ & \\
\hline Rocky Mountain Lower Montane-Foothill Shrubland & 8020 & $0.1 \%$ & $100 \%$ & $0.4 \%$ & & & $4 \%$ & $96 \%$ & $0.002 \%$ \\
\hline Colorado Plateau Mixed Low Sagebrush Shrubland & 4250 & $0.01 \%$ & $100 \%$ & $0.4 \%$ & & & $6 \%$ & $94 \%$ & \\
\hline Columbia Plateau Scabland Shrubland & 3775 & & $85 \%$ & $15 \%$ & & & $5 \%$ & $95 \%$ & \\
\hline Wyoming Basins Dwarf Sagebrush Shrubland and Steppe & 1107 & & $96 \%$ & $4 \%$ & & & $5 \%$ & $95 \%$ & \\
\hline \multicolumn{10}{|l|}{ Mixed Salt Desert Scrub and Greasewood } \\
\hline Inter-Mountain Basins Mixed Salt Desert Scrub & 95,681 & $2 \%$ & $96 \%$ & $2 \%$ & & & $57 \%$ & $43 \%$ & \\
\hline Inter-Mountain Basins Greasewood Flat & 58,269 & $0.005 \%$ & $98 \%$ & $2 \%$ & & & $86 \%$ & $14 \%$ & \\
\hline Inter-Mountain Basins Mat Saltbush Shrubland & 10,677 & & $99 \%$ & $1 \%$ & & & $50 \%$ & $50 \%$ & \\
\hline \multicolumn{10}{|l|}{ Warm Temperate Grasslands and Semi-Desert Grasslands } \\
\hline Western Great Plains Shortgrass Prairie & 258,868 & $13 \%$ & $87 \%$ & $0.05 \%$ & & & $84 \%$ & $16 \%$ & \\
\hline $\begin{array}{l}\text { Apacherian-Chihuahuan Semi-Desert Grassland and } \\
\text { Steppe }\end{array}$ & 249,336 & & $84 \%$ & $16 \%$ & & $0.001 \%$ & $59 \%$ & $41 \%$ & \\
\hline \multicolumn{10}{|l|}{ Warm Desert Shrublands } \\
\hline Sonoran Paloverde-Mixed Cacti Desert Scrub & 131,505 & & $63 \%$ & $37 \%$ & $0.02 \%$ & & $58 \%$ & $42 \%$ & \\
\hline Chihuahuan Creosotebush Desert Scrub & 92,472 & & $86 \%$ & $14 \%$ & & & $72 \%$ & $28 \%$ & $0.05 \%$ \\
\hline $\begin{array}{l}\text { Sonora-Mojave Creosotebush-White Bursage Desert } \\
\text { Scrub }\end{array}$ & 91,703 & & $26 \%$ & $74 \%$ & $0.001 \%$ & & $14 \%$ & $84 \%$ & $2 \%$ \\
\hline Chihuahuan Mixed Desert and Thornscrub & 21,071 & & $89 \%$ & $11 \%$ & & & $42 \%$ & $57 \%$ & \\
\hline
\end{tabular}


Components of sensitivity reflect common circumstances for these types found throughout some of the more remote and undeveloped landscape in the Western United States; but that still include substantial areas impacted by past and current ecological stressors. Relative vulnerability contributed by degraded landscape condition varies considerably, with most area by type falling in the low to moderate ranges. For range-wide summary statistics, seven of these vegetation types include $>50 \%$ of their area in the high to very high vulnerability ranges. Cool temperate grassland types, from the Columbia Plateau east to the Western Great Plains are represented here. These types are found in some of the most intensively cultivated regional landscapes of the types include in this study. Fire regime departure is a substantial contributor to vulnerability, and 16 types include $>50 \%$ of their area in the high to very high vulnerability ranges. These types tend to be concentrated in lower montane forests and woodlands, cool temperate grasslands, and cool semi-desert shrublands where wildfire suppression policies have resulted in altered successional pathways. Invasive plant models for this analysis primarily pertained to cool desert shrublands and cool temperate grassland types. Several sagebrush and related vegetation types include substantial areas that are indicated as being in the high or very high vulnerability ranges (e.g., Columbia Plateau Western Juniper Woodland and Savanna-54\%; Mojave Mid-Elevation Mixed Desert Scrub-33\%; Inter-Mountain Basins Big Sagebrush Steppe-30\%; Inter-Mountain Basins Big Sagebrush Shrubland-27\%), and the effects of invasive plants interact with alterations to wildfire regimes in most of these vegetation types. Vulnerability stemming from forest insect and disease risk applied only to forest and woodland types, and from a range-wide perspective, appear to have contributed less than other factors, but for some types, rather substantial area was measured within the moderate vulnerability range (e.g., Southern Rocky Mountain Mesic Montane Mixed Conifer Forest and Woodland-32\%; California Montane Jeffrey Pine-(Ponderosa Pine) Woodland-28\%).

Most notably among adaptive capacity measures, the topo-climatic variability is naturally quite low for all but some of the montane forest and woodland types in this region, as most desert shrublands and temperate grasslands occupy vast landscapes of relatively flat to gently rolling topography. Therefore, for most types, most of their area scored within the high to very high vulnerability ranges. Also, for many of these types that dominate the arid interior of Western North America, inherent species diversity is low and recovery from surface disturbance is relatively slow when compared with montane forests and shrublands. Functional species groups identified often centered on nitrogen fixation, soil stability, and other common characteristics of vegetation in semi-arid regions. Relatively low within-type diversity in one or more functional species group led to low scores for this component of climate change vulnerability. As a result, 14 types scored within the very high vulnerability range, while most others scored in the moderate range. Interestingly, only one "keystone" species was identified associated with any of these 52 assessed types. The black-tailed prairie dog (Cynomys ludovicianus) was associated with mixed-grass and shortgrass prairie types, but its individual climate change vulnerability was considered to be relatively low.

While the outputs of the HCCVI are most relevant and applicable to analysis of individual ecosystem types, and factors contributing to their relative vulnerability are differentially expressed across their type distribution, one can also combine mapped results for major types to detect patterns of relative vulnerability. Figure 8 depicts the combined results for all 52 types assessed here, by their $100 \mathrm{~km}^{2}$ hexagon summary unit. Since this set of types represent the predominant vegetation at lower and middle elevations across the region, they can summarize overall patterns of ecosystem type vulnerability for the region. With an extreme of 24 types occurring within a given hexagon, the figure depicts three ways of summarizing vulnerability patterns, using (left) the lowest (least vulnerable) scoring type per hexagon, (right) the highest (most vulnerable) scoring type, and (bottom) the average score of all types present. These views highlight a range of moderate to very high relative vulnerability across key regional landscapes, such as in the Mojave Desert, Columbia Basin, the Great Salt Lake Basin, the Colorado Front Range, the Nebraska Sandhills, and West Texas. 


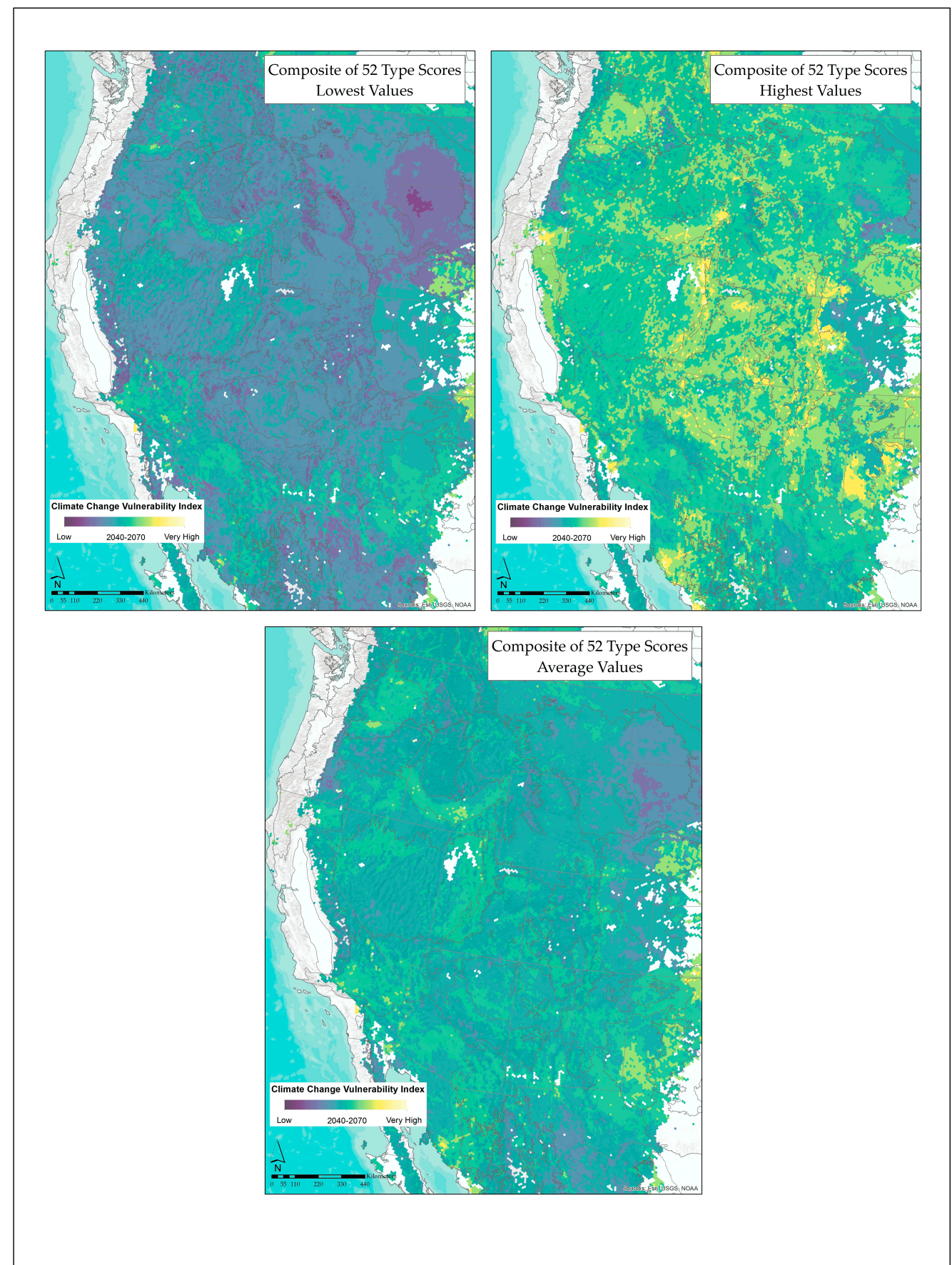

Figure 8. Overall Climate Change Vulnerability estimate for 2040-2070 summarized by $100 \mathrm{~km}^{2}$ hexagon for all 52 assessed types, with a minimum of one type and a maximum of 24 types occurring within each hexagon, displayed scores include the least, most, and average vulnerability scores (left to right to bottom).

\section{Discussion}

\subsection{Vulnerability and Adaptative Vegetation Management}

Here we have demonstrated an analytical framework to document relative climate-change vulnerabilities among major upland vegetation types that dominate desert and montane forests of the interior Western USA. While many of these types are well represented in protected and managed public lands [46] that does not shield them from effects of climate change. By integrating available 
information, we identified types and places where signals of climate change stress are emerging, and where they can be foreseen over upcoming decades. This effort drew inspiration from many similar efforts on the overall structure, measurements used, and available data, but here our analysis is based on synecology and facilitates practical application of results to vegetation at scales commonly addressed in biodiversity conservation and natural resource management. By applying a systematic framework to climate change vulnerability assessment, it generates actionable information targeted to both policy-makers and land managers in support of natural resource conservation decisions.

While traditional natural resource management has tended to be 'retrospective'-utilizing knowledge of past and current conditions to inform today's management actions-conservation professionals are increasingly required to more rigorously forecast future conditions. This forecasting strives to determine the nature and magnitude of change likely to occur, and then translate that knowledge to current decision-making timeframes. It is no longer sufficient to assess "how are we doing?" and then decide what actions should be prioritized for the upcoming 15-year management plan. One must now ask "how is it changing, and by when?" and then translate that knowledge back into actions to take within one or more planning horizons.

Climate change adaptation includes actions that enable ecosystems and people to better cope with or adjust to changing conditions. Some have categorized major strategies into three areas, including resistance, resilience, and facilitated transformation [47-49]. Where vulnerability assessments indicate low vulnerability over upcoming decades, management can concentrate on resistance-based strategies; aiming to prevent ecosystem degradation. Where moderate to high vulnerability is indicated, strategies focused on restoring resilience are the priority. Where vulnerability is indicated as being very high over upcoming decades, options for facilitated transformation need to be identified.

Results of this analysis suggest adaptation strategies that suit the character of the vegetation type. For example, as described in the results, warm desert shrublands and semi-desert grassland types already score into the high vulnerability range. It would be prudent for planners and managers to evaluate current landscape patterns and identify zones where they can anticipate plant invasions from neighboring vegetation [50]. Where degraded from prior land uses, restoration of native herb diversity and nitrogen fixing taxa are also needed. Monitoring for pollinator population trends, invasive plant expansion, and shrub regeneration, are also increasingly urgent.

Further north and upslope, pinyon-juniper woodlands currently tend to score in the low-moderate range of vulnerability, but my mid-century, they score in the moderate to high range of vulnerability. Actions to maintain or restore resilience in these forests are needed [51]. These could include protection of remaining "old growth" stands while restoring natural wildfire regimes and tree canopy densities in the surroundings. Over upcoming decades, as temperature and precipitation patterns change, models of wildfire regimes will need to be updated and customized to local conditions. Monitoring for invasive plant expansion, such as from cheatgrass (Bromus tectorum), effects of drought stress, and tree regeneration will all increase in urgency.

Looking out to the upcoming decades towards the mid-21st century, nearly all types assessed here would benefit from a set of resilience-based strategies, so these investments in the near-term may limit needs for more extreme measures later in the century.

\subsection{Methodological Issues}

The HCCVI could be considered an Indicator-Based Vulnerability Assessment (IBVA), where a series of indicators for exposure or resilience are measured and then combined to approximate relative climate change vulnerability. Tonmoy et al. [29] completed a meta-analysis of vulnerability assessments and provide useful insights into strengths and weaknesses in methods for IBVA design and indicator aggregation. Our HCCVI could be categorized as a hybrid IBVA that combines simulation modeling (e.g., for project climate conditions) with the present value of other indicators (e.g., for sensitivity and adaptive capacity measures) to arrive at a vulnerability score. We normalized each indicator and used an arithmetic mean for their combination. This approach to aggregation requires a high 
level of independence among component indicators and considerable knowledge of the relationship between each indicator and overall vulnerability. While these vegetation types are well understood and documented, and indicators used here reflect high-quality data, we still cannot presume all assumptions have been fully met with regards to aggregation rules.

In contrast to some of the relatively few other assessment methods for natural community types, we have limited our scope to well-described types characterized by native vegetation. Where others have chosen to assess socio-ecological systems $[17,18]$, the level of uncertainty increases considerably. While we acknowledge the relative utility of formally integrating human dimensions into ecosystem concepts, we feel that the introduced uncertainty is considerable. Our approach aims to limit this uncertainty by first assessing the natural community type, and then in subsequent steps, these outputs can be brought together with human dimensions affecting a given landscape of interest.

Also, in contrast to many other assessments, here we have emphasized measuring climate exposure along a trend line from the mid-20th century baseline through recent conditions, and into the future time frame of the upcoming decades. This trend-based approach helps to address the considerable uncertainty associated with climate projections by first grounding "current" measures from already observed climate change, and then by focusing on the upcoming decades though the mid-21st century.

One of the most significant methodological challenges to our framework is the application of the climate exposure measure. We anticipate much additional effort to better tie climate trend data more directly to driving ecological processes (e.g., biomass productivity, hydrologic regime, fire regime) to provide more robust predictions. Similarly, some factors affecting resilience will change over upcoming decades, and so the ability to create reliable forecasts of changing conditions, such as those resulting from future development patterns or invasive species spread, will add precision to overall resilience forecasts. Other challenges identified with this framework included the treatment of functional species groups and "keystone" species. While both concepts for vulnerability measures are desirable and likely provide important contributions, limits to current knowledge become apparent when one attempts to identify and assess species for each category. In addition, locating data sets for component measures that span the range of a given type will remain a challenge. A systematic and regional approach such as this that we have taken can highlight needs for investments in data sets critical to addressing climate change.

\section{Conclusions}

This framework is intended for widespread application and accumulation of results for many vegetation types. The summary spatial units chosen, including $100 \mathrm{~km}^{2}$ hexagons and ecoregion units, appear to be practical for this purpose. Some of the input raster layers (30-800 $\mathrm{m}$ pixel resolution) are also quite useful for subsequent application to decision making.

These outputs are also compatible with efforts to gauge the range-wide conservation status or risk of range-wide ecosystem collapse. For example, under the IUCN Red List of Ecosystems framework [52,53], Criterion C3 addresses environmental degradation over a 50-year timeframe including the current time period where degradation is expressed in terms of relative proportional extent of and ecosystem type affected at varying levels of relative severity. Since our results can express relative severity (i.e., very high-low climate change vulnerability) in $100 \mathrm{~km}^{2}$ increments across the range-wide extent of the type, they could apply directly to measuring $\mathrm{C} 3$ for red listing.

We believe that the framework illustrated provides a practical basis for accumulating spatially explicit scores for climate change vulnerability of major vegetation types. It also includes sufficient specificity to inform adaptive management responses. Continued investment in this type of analysis, encompassing more types and across national and international scales, should yield benefits to natural resource managers and conservation practitioners as they navigate the challenges posed by climate change over the upcoming decades.

Supplementary Materials: The following are available online at https:/databasin.org/galleries/ 6704179ca499490bafd2e9080df1908a. 
Author Contributions: Conceptualization, P.J.C. and H.H.H.; Data curation, J.C.H., S.L.A. and R.L.S.; Formal analysis, P.J.C., J.C.H., S.L.A. and M.M.K.; Funding acquisition, P.J.C. and H.H.H.; Investigation, P.J.C., J.C.H., M.S.R., S.L.A. and K.A.S.; Methodology, P.J.C., J.C.H., M.S.R., S.L.A., H.H.H. and M.M.K.; Project administration, P.J.C. and M.S.R.; Software, J.C.H. and S.L.A.; Supervision, H.H.H.; Validation, P.J.C., J.C.H., S.L.A., R.L.S and M.M.K.; Visualization, P.J.C., M.S.R., S.L.A., H.H.H., R.L.S. and M.M.K.; Writing-original draft, P.J.C.; Writing-review \& editing, J.C.H., S.L.A., H.H.H. and M.M.K.

Funding: This research was funded by the USDOI Bureau of Land Management, cooperative agreement number L13AC00243.

Acknowledgments: We wish to acknowledge the support of U.S. Department of Interior agencies, primarily the Bureau of Land Management and U.S. Fish and Wildlife Service, who have provided resources for this research. Numerous experts have provided review and insights throughout the design of this method and its implementation. Geoff Hammerson conducted climate change vulnerability assessments for animal species involved in this research. Patrick McIntyre provided technical interpretation for some vegetation types, and Don Faber-Langendoen provided editorial review. Mary Harkness and Kristin Snow provided essential support for database design and management.

Conflicts of Interest: The authors declare no conflict of interest. The funders had no role in the design of the study; in the collection, analyses, or interpretation of data; in the writing of the manuscript, or in the decision to publish the results.

\section{Appendix A. Methods Detail for Resilience Measures}

Individual measures for resilience were applied to each type. This appendix provides detailed explanation of procedures used for each measurement.

\section{Resilience-Ecosystem Sensitivity}

Below are described specific measures of sensitivity, including Landscape Condition, Invasive Plant Species, Fire Regime Departure, and Forest Insect and Disease Risk.

\section{Sensitivity-Landscape Condition}

Since human land uses, such as built infrastructure for transportation, urban development, industry, agriculture and other vegetation alterations, are depicted in maps that are periodically updated, they can be used in spatial models to make inferences about the status and trends in human-induced stress and ecological condition of ecosystems and landscapes at regional to global scales [54-57]. The spatial model of landscape condition used here [58] built on a growing body of published methods and software tools for ecological effects assessment and spatial modeling; all of which aim to characterize relative ecological condition of landscapes [59-61]. The model uses regionally available spatial data to transparently express user knowledge regarding the relative effects of land uses on natural ecosystems.

Values close to 1.0 indicate almost no measurable ecological impact from the land use at a given pixel. As described in [57], model parameters were calibrated, and subsequently validated using tens of thousands of field observations indicating relative ecological condition. The result is a map surface that provides relative index scores per pixel between 0.0 and 1.0. Calibration of this model against over 50,000 field occurrences ranked as $\mathrm{A}=$ excellent $\mathrm{B}=$ good, $\mathrm{C}=$ fair, and $\mathrm{D}=$ poor condition was used to identify thresholds in the 0.0-1.0 scale for applications. In this instance, we used one standard deviation above the mean of the index value for the $\mathrm{D}$ occurrences to determine the $\mathrm{C}$. vs. D threshold. The overall threshold value breaks are as follows; A-Rank $\geq 0.36$, B-Rank $\geq 0.30$, C-Rank $\geq 0.25$, D-Rank $<0.25$. Per pixel scores were summarized to average values per vegetation type per $100 \mathrm{~km}^{2}$ hexagon for display.

\section{Sensitivity—Invasive Plant Species}

Among desert shrubland and steppe, the effects of invasive species on ecosystem integrity is well known and there is considerable concern for their interactions with climate change [61]. Spatial models depicting likely presence and abundance of invasive annual grasses provide an important indication of vegetation condition, and therefore, relative sensitivity under the HCCVI framework. 
See [23] and [62] for further explanation of spatial models used here. Using the master database of over 20,000 invasive plant locality records with satellite imagery and a suite of environmental variables, inductive modeling was completed using Random Forests [41]. The resultant independently evaluated map surfaces represent invasive annual grass presence in five categories of expected absolute cover $(<5 \%, 5-15 \%, 16-25 \%, 26-45 \%$, and $>45 \%)$. The five models were then combined onto one surface with higher predicted invasive cover classes taking precedence over lower cover classes on a per pixel basis. These absolute cover values were translated to index scores to reflect " $1.0=$ most favorable" to " $0.0=$ least favorable" index values as follows: $<5 \%=1.0,5-15 \%=0.80,16-25 \%=0.6,26-45 \%=0.4$, $>45 \%=0.2$. These per pixel scores were then summarized to average values per vegetation type per $100 \mathrm{~km}^{2}$ hexagon. This measure applied to desert shrubland and grassland vegetation types where invasive annual grasses have substantial impact.

\section{Sensitivity-Fire Regime Departure}

Using estimates of fire frequency and successional rates, fire regime models predict the relative proportion of natural successional stages one might expect to encounter for a community type across a given landscape. They are therefore useful for indicating ecosystem degradation due to wildfire suppression or other human-caused alteration [63]. The US Interagency LANDFIRE program provides both quantitative reference models of vegetation states (i.e., successional stages) and transitions, as well as spatial models of wildfire regime departure (measured in percent of departure) that compare observed vs. predicted aerial extent of each successional stage [33]. For each vegetation type treated in this project, these percent departure values (in 10\% increments) were translated to index scores to reflect " $1.0=$ most favorable" to " $0.0=$ least favorable" index values as follows: FRCC $1=1.0$, FRCC $2=0.5$, and FRCC $3=0.15$. These per pixel scores were then summarized to average values per vegetation type per $100 \mathrm{~km}^{2}$ hexagon.

\section{Sensitivity-Forest Insect and Disease Risk}

Forest insect and disease impacts on Western US forests and woodlands are becoming pronounced, especially with increasing frequency of relatively mild winters [64]. With increasing rates of overwintering survival of both native and introduced insects, as well as compounded effects of drought [65] there is increasing potential for substantial disruption in forest stand structure, composition, and interacting effects with other natural disturbance processes [66]. The National Insect and Disease Risk Map defines forest areas where, "the expectation that, without remediation, at least $25 \%$ of standing live basal area greater than one inches in diameter will die over a 15-year timeframe (2013-2027) due to insects and diseases" [67]. The resultant $240 \mathrm{~m}$ pixel resolution map represents insect and disease risk along a $0.0-1.0$ ramp depicting low to high severity of predicted biomass loss (e.g., $0.05=5 \%, 0.25=25 \%$, $0.35=35 \%$, etc.). These index values were flipped in order to reflect our " $1.0=$ most favorable" to " $0.0=$ least favorable" index values. These per pixel scores were then summarized to average values per vegetation type per $100 \mathrm{~km}^{2}$ hexagon. This index was applied only to forest and woodland types where forest insects and diseases have substantial impact.

\section{Resilience-Ecosystem Adaptive Capacity}

Below are described several measures of adaptive capacity, including diversity within functional species groups, climate change vulnerability of "keystone species," and topo-climate variability.

\section{Diversity within Characteristic Functional Species Groups}

Natural communities may include several functional groups, or groups of organisms that pollinate, graze, disperse seeds, fix nitrogen, decompose organic matter, depredate smaller organisms, or perform other functions $[68,69]$. Functional species groups (FSGs) form a link between key ecosystem processes and structures and ecological resilience. Experimental evidence gathered over recent decades supports the theoretical prediction that communities with functional groups made up of increasingly diverse 
members tend to be more resilient to perturbations [27]. Therefore, the more diverse the FSG (as measured by taxonomic richness), the greater the likelihood that at least one taxon will have characteristics that allow it to continue to perform its function in the community as climate changes.

Approaches to identifying FSGs for natural communities center on analysis of specific traits in response to environmental constraints [70]. In this effort, environmental settings, dynamics processes, species responses to those settings and processes, and key biotic interactions required for maintenance of each vegetation type, were evaluated to identify the most critical ecological processes and their related FSG. FSGs applicable to the vegetation types in this project included nitrogen fixers, biotic pollinators, biotic seed dispersers, biological soil crusts, perennial cool season grasses, perennial warm season graminoids, halophytes, xerophytes, and pyrophytes. Within each identified group, a listing of characteristic species is included based on existing documentation for the type. Lists of functional species groups used are described in the supporting information (Supplementary Materials).

In each instance, available literature was reviewed to document each group, and for each vegetation type, score them along a 0.0 to 1.0 scale. Due to limited knowledge of variation in FSG composition across the Western US, the same score was applied consistently across the entire distribution of each vegetation type, and we scored FSG diversity in three categories of Low, Medium, or High. While ranges varied by FSG, generally those groups with $1-5$ species were scored as low $(=0.15,6-15$ species as medium (0.5), and $>15$ species as high (1.0). Where several FSGs were identified for a given vegetation type, the lowest scoring FSG was applied to the type overall, as it would likely have a strong controlling effect on resilience.

\section{Vulnerability of Keystone Species}

To assess community resilience, it is important to consider the relative climate change vulnerability of species that play particularly important functional roles. We use the term "keystone species" here to refer to any species that, due to their key functional role in the community, if extirpated or reduced in abundance, could cause disproportionate effects on the populations of other species that characterize the community. Determining the species that can be considered keystone requires an understanding of the natural history of many species in the community being assessed. Although there are quantitative means of identifying keystone species via food web analysis [71], these methods can be time and data intensive. However, identification of potential keystone species may follow directly from the above process "diversity within functional species groups". That is, if an important ecosystem function is represented by just one species, that species is likely providing some "keystone" function for the purposed of this analysis. We reviewed all lists of species across our FSGs and identified a set of keystone species for each vegetation type.

We assessed keystone species vulnerability using the NatureServe Climate Change Vulnerability Index (CCVI), a trait-based tool that allows relatively rapid assessment of suites of species and is applicable to all terrestrial and aquatic plant and animal species [24]. The CCVI places species on a categorical scale from extremely vulnerable to those likely to benefit from climate change. For this effort, the CCVI was applied to the distribution of each species within each of the primary ecoregions that make up the distribution of the vegetation type. The CCVI categories were translated to a numerical scale (0.0-1.0 scale) for combination with other adaptive capacity measures.

\section{Topo-Climatic Variability}

Natural communities occur across a range of both macro and micro-climates. For example, some major temperate grassland types of the Western Great Plains form the upland 'matrix' of an ecoregion and in topography of limited relief, while other woodland types occur in microclimates formed by rugged canyons and low mountain ranges. Their current distributions are largely based on both regional and local-scale responses to temperature and precipitation. The relative variability in climate encompassed by the distribution of a given community can provide another useful indication of adaptive capacity under changing climate [72]. The idea of climate change 'velocity' [73] has been 
proposed as a measure of climate change exposure, and it captures in part the interaction of changing climate with topography. The measure is derived by dividing the rate of projected climate change in units of ${ }^{\circ} \mathrm{C}$ per year by the rate of spatial climate variability, i.e., the temperature differential of adjacent grid cells, measured in ${ }^{\circ} \mathrm{C} \mathrm{km}^{-1}$. Areas with relatively rugged topography and elevational gradients will support a greater diversity of microclimate conditions (re: low velocity) as compared with areas of flat topography. Therefore, for the same increment of climate change and time-period, a given species would be required to migrate a shorter distance in areas of rugged topography as compared with expansive flat landscapes.

Since we provide for independent measures of climate change exposure with the HCCVI framework, we used maps of terrain ruggedness to express the influence of topography on microclimate variability. The terrain ruggedness index (TRI) provided by Riley et al. [74] was used with $90 \mathrm{~m}$ digital elevation data of North America. TRI is the sum change in elevation between a given grid cell and its eight neighboring grid cells. For example, a cell located at $200 \mathrm{~m}$ elevation, surrounded by four cells at $100 \mathrm{~m}$ and four more cells at $125 \mathrm{~m}$ would yield a TRI of $700(400+500-200=700)$. The topo-climatic variability map was derived by normalizing TRI scores to the $0.01-1.0$ scale using extreme TRI estimates as projected for North America (TRI $=6196$ ). We overlaid this normalized map with distributions of each vegetation type to arrive at per pixel scores and then summarized them by $100 \mathrm{~km}^{2}$ hexagon.

\section{Appendix B. Proportional Area for All Component and Composite HCCVI Scores for 52 Major Vegetation Types (Supplied as Separate File)}

Again, the summarized results for overall climate change vulnerability of the 52 assessed types are found in Appendix B. Type-specific map, text, and tabular summary information is accessible within Supplementary Materials (see: https://databasin.org/galleries/6704179ca499490bafd2e9080df1908a).

\section{References}

1. Swetnam, T.W.; Betancourt, J.L. Mesoscale disturbance and ecological response to decadal climatic variability in the American Southwest. J. Clim. 1998, 11, 3128-3147. [CrossRef]

2. Wells, P.V. Paleobiogeography of montane islands in the Great Basin since the last glaciopluvial. Ecol. Monogr. 1983, 53, 341-382. [CrossRef]

3. Betancourt, J.L.; Van Devender, T.R.; Martin, P.S. (Eds.) Packrat Middens: The Last 40,000 Years of Biotic Change; University of Arizona Press: Tucson, AZ, USA, 1990.

4. Barros, R.V.; Field, C.B.; Dokken, D.J.; Mastrandrea, M.D.; Mach, K.J.; Bilir, T.E.; Chatterjee, M.; Ebi, K.L.; Estrada, Y.O.; Genova, R.C.; et al. Climate Change 2014: Impacts, Adaptation, and Vulnerability-Part B: Regional Aspects; Cambridge University Press: New York, NY, USA, 2014.

5. Mantyka-pringle, C.S.; Martin, T.G.; Rhodes, J.R. Interactions between climate and habitat loss effects on biodiversity: A systematic review and meta-analysis. Glob. Chang. Biol. 2012, 18, 1239-1252. [CrossRef]

6. Allen, C.D.; Birkeland, C.; Stuart Chapin, F., III; Groffman, P.M.; Guntenspergen, G.R.; Knapp, A.; McGuire, A.D.; Mulholland, P.J.; Peters, D.P.C.; Roby, D.D.; et al. Thresholds of Climate Change in Ecosystems; A Report by the US Climate Change Science Program and the Subcommittee on Global Change Research; US Geological Survey, Department of the Interior: Washington, DC, USA, 2009.

7. Finch, D.M. Climate Change in Grasslands, Shrublands, and Deserts of the Interior American West: A Review and Needs Assessment; US Department of Agriculture, Forest Service, Rocky Mountain Research Station: Fort Collins, CO, USA, 2012.

8. Thomas, C.D.; Cameron, A.; Green, R.E.; Bakkenes, M.; Beaumont, L.J.; Collingham, Y.C.; Erasmus, B.F.N.; De Siqueira, M.F.; Grainger, A.; Hannah, L.; et al. Extinction risk from climate change. Nature 2004, 427, 145. [CrossRef] [PubMed]

9. Laidre, K.L.; Stirling, I.; Lowry, L.F.; Wiig, Ø.; Heide-Jørgensen, M.P.; Ferguson, S.H. Quantifying the sensitivity of Arctic marine mammals to climate-induced habitat change. Ecol. Appl. 2008, 18, S97-S125. [CrossRef] [PubMed]

10. Rowland, E.L.; Davison, J.E.; Graumlich, L.J. Approaches to evaluating climate change impacts on species: A guide to initiating the adaptation planning process. Environ. Manag. 2008, 47, 322-337. [CrossRef] [PubMed] 
11. Pacifici, M.; Foden, W.B.; Visconti, P.; Watson, J.E.M.; Butchart, S.H.; Kovacs, K.M.; Scheffers, B.R.; Hole, D.G.; Martin, T.G.; Akçakaya, H.R.; et al. Assessing species vulnerability to climate change. Nat. Clim. Chang. 2015, 5, 215. [CrossRef]

12. Foden, W.B.; Young, B.E.; Akçakaya, H.R.; Garcia, R.A.; Hoffmann, A.A.; Stein, B.A.; Thomas, C.D.; Wheatley, C.J.; Bickford, D.; Carr, J.A.; et al. Climate change vulnerability assessment of species. Wiley Interdiscip. Rev. Clim. Chang. 2018, 10, e551. [CrossRef]

13. Swanston, C.; Janowiak, M.; Iverson, L.; Parker, L.; Mladenoff, D.; Brandt, L.; Butler, P.; Pierre, M.S.; Prasad, A.; Matthews, S.; et al. Ecosystem Vulnerability Assessment and Synthesis; US Department of Agriculture, Forest Service, Rocky Mountain Research Station: Fort Collins, CO, USA, 2010.

14. Rustad, L.; Campbell, J.; Dukes, J.S.; Huntington, T.; Lambert, K.F.; Mohan, J.; Rodenhouse, N. Changing Climate, Changing Forests: The Impacts of Climate Change on Forests of the Northeastern United States and Eastern Canada; US Department of Agriculture, Forest Service, Rocky Mountain Research Station: Fort Collins, CO, USA, 2012.

15. Schneider, R.R. Alberta's Natural Subregions under a Changing Climate: Past, Present, and Future; Alberta Biodiversity Monitoring Institute: Edmonton, AB, Canada, 2013.

16. Hamann, A.; Roberts, D.R.; Barber, Q.E.; Carroll, C.; Nielsen, S.E. Velocity of climate change algorithms for guiding conservation and management. Glob. Chang. Biol. 2015, 21, 997-1004. [CrossRef]

17. Lindner, M.; Maroschek, M.; Netherer, S.; Kremer, A.; Barbati, A.; Garcia-Gonzalo, J.; Seidl, R.; Delzon, S.; Corona, P.; Kolström, M.; et al. Climate change impacts, adaptive capacity, and vulnerability of European forest ecosystems. For. Ecol. Manag. 2010, 259, 698-709. [CrossRef]

18. Cinner, J.E.; Huchery, C.; Darling, E.S.; Humphries, A.T.; Graham, N.A.J.; Hicks, C.C.; Marshall, N.; McClanahan, T.R. Evaluating Social and Ecological Vulnerability of Coral Reef Fisheries to Climate Change. PLoS ONE 2013, 8, e74321. [CrossRef] [PubMed]

19. Thorne, J.H.; Boynton, R.M.; Holguin, A.J.; Stewart, J.A.; Bjorkman, J. A Climate Change Vulnerability Assessment of California's Terrestrial Vegetation; California Department of Fish and Wildlife: Sacramento, CA, USA, 2016.

20. Flint, L.E.; Flint, A.L.; Thorne, J.H.; Boynton, R.M. Fine-scale hydrological modeling for regional applications: Model development and performance. Ecol. Process. 2013, 2, 25. [CrossRef]

21. Li, D.; Wu, S.; Liu, L.; Zhang, Y.; Li, S. Vulnerability of the global terrestrial ecosystems to climate change. Glob. Chang. Boil. 2018, 24, 4095-4106. [CrossRef] [PubMed]

22. Comer, P.J.; Young, B.; Schulz, K.; Kittel, G.; Unnasch, B.; Braun, D.; Hammerson, G.; Smart, L.; Hamilton, H.; Auer, S.; et al. Climate Change Vulnerability and Adaptation Strategies for Natural Communities: Piloting Methods in the Mojave and Sonoran Deserts; Report to US Fish and Wildlife Service; NatureServe: Arlington, VA, USA, 2012.

23. Comer, P.J.; Crist, P.J.; Reid, M.S.; Hak, J.; Hamilton, H.; Unnasch, B.; Kutner, L. A Rapid Ecoregional Assessment of the Central Basin and Range Ecoregion. Report, Appendices, and Databases Provided to the Bureau of Land Management. Available online: https://landscape.blm.gov/geoportal/catalog/REAs/REAs.page (accessed on 5 July 2019).

24. Young, B.; Byers, E.; Gravuer, K.; Hall, K.; Hammerson, G.; Redder, A. Guidelines for Using the NatureServe Climate Change Vulnerability Index; NatureServe: Arlington, VA, USA, 2011.

25. Holling, C.S. Resilience and stability of ecological systems. Annu. Rev. Ecol. Syst. 1973, 4, 1-23. [CrossRef]

26. Gunderson, L.H. Ecological resilience-In theory and application. Annu. Rev. Ecol. Syst. 2000, 31, 425-439. [CrossRef]

27. Walker, B.; Holling, C.S.; Carpenter, S.R.; Kinzig, A. Resilience, adaptability and transformability in social-ecological systems. Ecol. Soc. 2004, 9. [CrossRef]

28. Magness, D.R.; Morton, J.M.; Huettmann, F.; Chapin III, F.S.; McGuire, A.D. A climate-change adaptation framework to reduce continental-scale vulnerability across conservation reserves. Ecosphere 2011, 2, 1-23. [CrossRef]

29. Tonmoy, F.N.; El-Zein, A.; Hinkel, J. Assessment of vulnerability to climate change using indicators: A meta-analysis of the literature. Wiley Interdiscip. Rev. Clim. Chang. 2014, 5, 775-792. [CrossRef]

30. Wiken, E.; Jiménez Nava, F.; Griffith, G. North American Terrestrial Ecoregions_Level III; Commission for Environmental Cooperation: Montreal, QC, Canada, 2011.

31. Comer, P.; Faber-Langendoen, D.; Evans, R.; Gawler, S.; Josse, C.; Kittel, G.; Snow, K. Ecological Systems of the United States: A Working Classification of US Terrestrial Systems; NatureServe: Arlington, VA, USA, 2003. 
32. Comer, P.J.; Schulz, K.A. Standardized ecological classification for mesoscale mapping in the southwestern United States. Rangel. Ecol. Manag. 2007, 60, 324-335. [CrossRef]

33. Rollins, M.G. LANDFIRE: A nationally consistent vegetation, wildland fire, and fuel assessment. Int. J. Wildland Fire 2009, 18, 235-249. [CrossRef]

34. Comer, P.J.; Hak, J.C.; Josse, C.; Smyth, R. Long-term Change in Extent and Current Protection of Terrestrial Ecosystem Diversity in the Temperate and Tropical Americas. PLoS ONE 2019. Unpublished work.

35. Kling, M.M.; Auer, S.; Comer, P.J.; Ackerly, D.D.; Hamilton, H.H. Multiple dimensions of ecological vulnerability to climate change. Global Change Biology 2019. Unpublished work.

36. O'Donnell, M.S.; Ignizio, D.A. Bioclimatic predictors for supporting ecological applications in the conterminous United States. US Geol. Surv. Data Ser. 2012, 691, 1-10.

37. Sheehan, T.; Bachelet, D. and Ferschweiler, K.; Projected major fire and vegetation changes in the Pacific Northwest of the conterminous United States under selected CMIP5 climate futures. Ecol. Model. 2015, 317, 16-29. [CrossRef]

38. Oyler, J.W.; Ballantyne, A.; Jencso, K.; Sweet, M.; Running, S.W. Creating a topoclimatic daily air temperature dataset for the conterminous United States using homogenized station data and remotely sensed land skin temperature. Int. J. Climatol. 2015, 35, 2258-2279. [CrossRef]

39. Daly, C.; Halbleib, M.; Smith, J.I.; Gibson, W.P.; Doggett, M.K.; Taylor, G.H.; Curtis, J.; Pasteris, P.P. Physiographically sensitive mapping of climatological temperature and precipitation across the conterminous United States. Int. J. Clim. 2008, 28, 2031-2064. [CrossRef]

40. Wang, T.; Hamann, A.; Spittlehouse, D.; Carroll, C. Locally downscaled and spatially customizable climate data for historical and future periods for North America. PLoS ONE 2016, 11, e0156720. [CrossRef]

41. Liaw, A.; Wiener, M. Classification and regression by randomForest. R News 2002, 2, 18-22.

42. Bahn, V.; McGill, B.J. Testing the predictive performance of distribution models. Oikos 2013, 122, 321-331. [CrossRef]

43. Gregorutti, B.; Michel, B.; Saint-Pierre, P. Grouped variable importance with random forests and application to multiple functional data analysis. Comput. Stat. Data Anal. 2015, 90, 15-35. [CrossRef]

44. Damschen, E.I.; Baker, D.V.; Bohrer, G.; Nathan, R.; Orrock, J.L.; Turner, J.R.; Brudvig, L.A.; Haddad, N.M.; Levey, D.J.; Tewksbury, J.J. How fragmentation and corridors affect wind dynamics and seed dispersal in open habitats. Proc. Natl. Acad. Sci. USA 2014, 111, 3484-3489. [CrossRef] [PubMed]

45. Pausas, J.G.; Keeley, J.E. Abrupt climate-independent fire regime changes. Ecosystems 2014, 17, 1109-1120. [CrossRef]

46. Aycrigg, J.L.; Davidson, A.; Svancara, L.K.; Gergely, K.J.; McKerrow, A.; Scott, J.M. Representation of ecological systems within the protected areas network of the continental United States. PLoS ONE 2013, 8, e54689. [CrossRef] [PubMed]

47. Keith, D.A.; Rodriguez, J.P.; Rodríguez-Clark, K.M.; Nicholson, E.; Aapala, K.; Alonso, A.; Asmüssen, M.; Bachman, S.; Basset, A.; Barrow, E.G.; et al. Scientific Foundations for an IUCN Red List of Ecosystems. PLoS ONE 2013, 8, e62111. [CrossRef] [PubMed]

48. Bland, L.; Keith, D.A.; Miller, R.M.; Murray, N.J.; Rodríguez, J.P. Guidelines for the Application of IUCN Red List of Ecosystems Categories and Criteria, Version 1.1; IUCN: Gland, Switzerland, 2016.

49. Hansen, L.; Biringer, J.L.; Hoffman, J. Buying Time: A User's Manual to Building Resistance and Resilience to Climate Change in Natural Systems; WWF: Gland, Switzerland, 2003.

50. Millar, C.I.; Stephenson, N.L.; Stephens, S.L. Climate change and forests of the future: Managing in the face of uncertainty. Ecol. Appl. 2007, 17, 2145-2151. [CrossRef] [PubMed]

51. Chambers, J.C.; Beck, J.L.; Campbell, S.; Carlson, J.; Christiansen, T.J.; Clause, K.J.; Dinkins, J.B.; Doherty, K.E.; Griffin, K.A.; Havlina, D.W.; et al. Using Resilience and Resistance Concepts to Manage Threats to Sagebrush Ecosystems, Gunnison Sage-Grouse, and Greater Sage-Grouse in Their Eastern Range: A Strategic Multi-Scale Approach; Department of Agriculture, Forest Service, Rocky Mountain Research Station: Fort Collins, CO, USA.

52. Bachelet, D.; Ferschweiler, K.; Sheehan, T.; Strittholt, J. Climate change effects on southern California deserts. J. Arid Environ. 2016, 127, 17-29. [CrossRef]

53. Thorne, J.H.; Choe, H.; Stine, P.A.; Chambers, J.C.; Holguin, A.; Kerr, A.C.; Schwartz, M.W. Climate change vulnerability assessment of forests in the Southwest USA. Clim. Chang. 2018, 148, 387-402. [CrossRef] 
54. Sanderson, E.W.; Jaiteh, M.; Levy, M.A.; Redford, K.H.; Wannebo, A.V.; Woolmer, G. The human footprint and the last of the wild: The human footprint is a global map of human influence on the land surface, which suggests that human beings are stewards of nature, whether we like it or not. AIBS Bull. 2002, 52, 891-904.

55. Theobald, D.M. A general model to quantify ecological integrity for landscape assessments and US application. Landsc. Ecol. 2013, 28, 1859-1874. [CrossRef]

56. Haddad, N.M.; Brudvig, L.A.; Clobert, J.; Davies, K.F.; Gonzalez, A.; Holt, R.D.; Lovejoy, T.E.; Sexton, J.O.; Austin, M.P.; Collins, C.D.; et al. Habitat fragmentation and its lasting impact on Earth's ecosystems. Sci. Adv. 2015, 1, e1500052. [CrossRef]

57. Hak, J.C.; Comer, P.J. Modeling landscape condition for biodiversity assessment-application in temperate North America. Ecol. Indic. 2017, 82, 206-216. [CrossRef]

58. Riitters, K.H.; Wickham, J.D. How far to the nearest road? Front. Ecol. Environ. 2003, 1, 125-129. [CrossRef]

59. Hansen, A.J.; Knight, R.L.; Marzluff, J.M.; Powell, S.; Brown, K.; Gude, P.H.; Jones, K. Effects of exurban development on biodiversity: Patterns, mechanisms, and research needs. Ecol. Appl. 2005, 15, 1893-1905. [CrossRef]

60. Leu, M.; Hanser, S.E.; Knick, S.T. The human footprint in the west: A large-scale analysis of anthropogenic impacts. Ecol. Appl. 2008, 18, 1119-1139. [CrossRef] [PubMed]

61. Abatzoglou, J.T.; Kolden, C.A. Climate change in western US deserts: Potential for increased wildfire and invasive annual grasses. Rangel. Ecol. Manag. 2011, 64, 471-478. [CrossRef]

62. Hak, J.C.; Comer, P.J. Modeling Invasive Annual Grass Vulnerability in the Cold Deserts of the Intermountain West. Rangel. Ecol. Manag. 2019. Unpublished work.

63. Swaty, R.; Blankenship, K.; Hagen, S.; Fargione, J.; Smith, J.; Patton, J. Accounting for ecosystem alteration doubles estimates of conservation risk in the conterminous United States. PLoS ONE 2011, 6, e23002. [CrossRef] [PubMed]

64. Kurz, W.A.; Dymond, C.C.; Stinson, G.; Rampley, G.J.; Neilson, E.T.; Carroll, A.L.; Ebata, T.; Safranyik, L.; Kurz, W. Mountain pine beetle and forest carbon feedback to climate change. Nature 2008, 452, 987-990. [CrossRef]

65. Breshears, D.D.; Cobb, N.S.; Rich, P.M.; Price, K.P.; Allen, C.D.; Balice, R.G.; Romme, W.H.; Kastens, J.H.; Floyd, M.L.; Belnap, J.; et al. Regional vegetation die-off in response to global-change-type drought. Proc. Natl. Acad. Sci. USA 2005, 102, 15144-15148. [CrossRef]

66. Allen, C.D.; Macalady, A.K.; Chenchouni, H.; Bachelet, D.; McDowell, N.; Vennetier, M.; Kitzberger, T.; Rigling, A.; Breshears, D.D.; Hogg, E.; et al. A global overview of drought and heat-induced tree mortality reveals emerging climate change risks for forests. For. Ecol. Manag. 2010, 259, 660-684. [CrossRef]

67. Krist, F.J., Jr.; Ellenwood, J.R.; Wood, M.E.; McMahan, A.J.; Cowardin, J.P.; Ryerson, D.E.; Sapio, F.J.; Zweifler, M.O.; Romero, A.S. 2027 National Insect and Disease Forest Risk Assessment 2013; USDA Forest Service, Forest Health Technology Enterprise Team: Fort Collins, CO, USA, 2013.

68. Rosenfeld, J.S. Functional redundancy in ecology and conservation. Oikos 2002, 98, 156-162. [CrossRef]

69. Folke, C.; Carpenter, S.; Walker, B.; Scheffer, M.; Elmqvist, T.; Gunderson, L.; Holling, C.S. Regime shifts, resilience, and biodiversity in ecosystem management. Annu. Rev. Ecol. Evol. Syst. 2004, 35, 557-581. [CrossRef]

70. Díaz, S.; Cabido, M. Vive la difference: Plant functional diversity matters to ecosystem processes. Trends Ecol. Evol. 2001, 16, 646-655. [CrossRef]

71. Ebenman, B.; Jonsson, T. Using community viability analysis to identify fragile systems and keystone species. Trends Ecol. Evol. 2005, 20, 568-575. [CrossRef] [PubMed]

72. Ackerly, D.D.; Loarie, S.R.; Cornwell, W.K.; Weiss, S.B.; Hamilton, H.; Branciforte, R.; Kraft, N.J.B. The geography of climate change: Implications for conservation biogeography. Divers. Distrib. 2010, 16, 476-487. [CrossRef]

73. Loarie, S.R.; Duffy, P.B.; Hamilton, H.; Asner, G.P.; Field, C.B.; Ackerly, D.D. The velocity of climate change. Nature 2009, 462, 1052. [CrossRef] [PubMed]

74. Riley, S.J. Index that quantifies topographic heterogeneity. Intermt. J. Sci. 1999, 5, $23-27$.

(C) 2019 by the authors. Licensee MDPI, Basel, Switzerland. This article is an open access article distributed under the terms and conditions of the Creative Commons Attribution (CC BY) license (http://creativecommons.org/licenses/by/4.0/). 